\title{
An unexpected formation of a 14-membered Cyclodepsipeptide
}

\author{
Iliev, Boyan ; Linden, Anthony ; Heimgartner, Heinz
}

\begin{abstract}
The treatment of diluted solutions of the hydroxy diamides $6 \mathrm{a}$ and $6 \mathrm{~b}$ in toluene with $\mathrm{HCl}$ gas at $100^{\circ}$ gave the dimeric, 14 -membered cyclodepsipeptide 10 in up to $72 \%$ yield (Scheme 3 ). The same product was formed from the linear dimer of $6 \mathrm{~b}$, the depsipeptide 11 , under the same conditions (cf. Scheme 4). All attempts to prepare the cyclic seven-membered monomer 9, starting with different precursors and using different lactonization methods failed, and 10 was the only product which was isolated (cf. Scheme 6). For example, the reaction of the ester 20 with $\mathrm{NaH}$ in toluene at $80^{\circ}$ led exclusively to the cyclodimer 10. On the other hand, the base-catalyzed cyclization of the hydroxy diester 22, which is the 'O-analogue' of 20, yielded neither the seven- membered dilactone, nor the 14membered tetralactone, but only the known trimer 23 and tetramer 24 of 2,2- dimethylpropano-3-lactone (cf. Scheme 7).
\end{abstract}

DOI: https://doi.org/10.1002/hlca.200390262

Posted at the Zurich Open Repository and Archive, University of Zurich

ZORA URL: https://doi.org/10.5167/uzh-80019

Journal Article

Accepted Version

Originally published at:

Iliev, Boyan; Linden, Anthony; Heimgartner, Heinz (2003). An unexpected formation of a 14-membered Cyclodepsipeptide. Helvetica Chimica Acta, 86(9):3215-3234.

DOI: https://doi.org/10.1002/hlca.200390262 
Prof. Dr. H. Heimgartner Tel.: 01/635 4282 Fax : 01/635 6836

e-mail: heimgart@oci.unizh.ch

\section{An Unexpected Formation of a 14-Membered}

\section{Cyclodepsipeptide}

by Boyan Iliev ${ }^{1)}$, Anthony Linden, and Heinz Heimgartner*

Organisch-chemisches Institut der Universität Zürich, Winterthurerstrasse 190, CH-8057

Zürich

${ }^{1)}$ Part of the planned Ph.D. thesis of B.I., Universität Zürich. 
The treatment of diluted solutions of the hydroxydiamides $\mathbf{6 a}$ and $\mathbf{6 b}$ in toluene with $\mathrm{HCl}$ gas at $100^{\circ}$ gave the dimeric, 14-membered cyclodepsipeptide $\mathbf{1 0}$ in up to $72 \%$ yield (Scheme 3). The same product was formed from the linear dimer of $\mathbf{6 b}$, the depsipeptide $\mathbf{1 1}$, under the same conditions (Scheme 4). All attempts to prepare the cyclic 7-membered monomer 9, starting with different precursors and using different lactonization methods failed, and $\mathbf{1 0}$ was the only product which was formed (Scheme 6). For example, the reaction of the ester $\mathbf{2 0}$ with $\mathrm{NaH}$ in toluene at $80^{\circ}$ led exclusively to the cyclodimer 10. On the other hand, the base catalyzed cyclization of the hydroxydiester 22, which is the 'O-analogue' of $\mathbf{2 0}$, yielded neither the 7-membered dilactone, nor the 14-membered tetralactone, but only the known trimer $\mathbf{2 3}$ and tetramer $\mathbf{2 4}$ of 2,2-dimethylpropiolactone (Scheme 7). 


\section{Introduction}

The continuous and current interest in cyclic depsipeptides is a result of their well known biological activity. A large number of them have been isolated from natural sources, mainly from marine or surface cultures of the corresponding microorganisms (cf. [1-8]). Typical examples are the antibiotics valinomycin [9-11] and the enniatins [12], which act as ionophores [13]. The most demanding step in the synthesis of such compounds is the cyclization. As they contain amide groups and at least one ester group in the core, the cyclic depsipeptides could be prepared by the formation of either the amide or ester bonds as the ring closure step.

The cyclization via amide-bond formation (lactamization; e.g. [14-16]) is usually carried out by following protocols for the synthesis of cyclopeptides using coupling reagents. On the other hand, successful cyclizations via ester-bond formation (lactonization; e.g. [17-19]) have also been described. In the last few years, the number of reports on the use of macrolactonizations in the preparation of cyclodepsipeptides has increased remarkably [68][20][21]. A useful method for the ring closure of depsipeptides which contain $\alpha, \alpha$-disubstituted $\alpha$-amino acids is the so-called 'direct amide cyclization' method, developed in our laboratory [22-28]. The basic concept is that an amide of type $\mathbf{1}$ in a toluene solution or suspension is treated with dry $\mathrm{HCl}$ gas. Cyclization by elimination of the corresponding ammonium chloride leads to the intermediate 1,3-oxazol-5(4H)-one of type 2. In the absence of other nucleophiles, the oxazolone undergoes a ring enlargement via intramolecular nucleophilic attack of the hydroxyl group at the carbonyl C-atom of the neighboring lactone group, leading to the depsipeptide 3 (Scheme 1). 
<smiles>[R]N(C)C(=O)C(C)(C)NC(=O)CCCO</smiles>

$1 \mathrm{R}=\mathrm{Me}, \mathrm{Ph}$

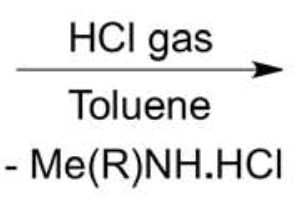

$\mathrm{NH} . \mathrm{HCl}$<smiles>CC1(C)[NH2+]C(CCCO)OC1=O</smiles>

2

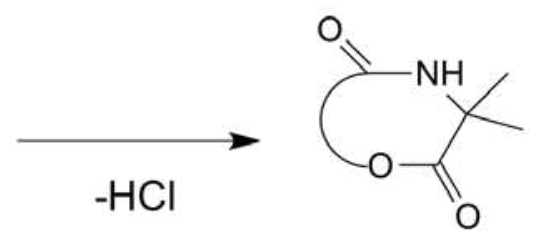

3

As was reported earlier, this method has been used efficiently for the synthesis of morpholine2,5-diones (i.e. 6-membered cyclic depsipeptides) [23][29] as well as for some 9-, 12-, 15[23], 16-[27] and 19-membered rings [30]. For the preparation of the 6-, 9-, 12- and 15membered rings of type $\mathbf{3}$, the linear precursors $\mathbf{1}$ have been prepared by coupling $\alpha$-hydroxy acids with $2 H$-azirin-3-amines, whereas $\beta$-hydroxy acids and $2 H$-azirin-3-amines led to the precursors of the 16- and 19-membered cyclodepsipeptides. The azirines themselves have been a target of our studies for some years [31-36], mainly because they proved to be useful synthons for $\alpha, \alpha$-disubstituted $\alpha$-amino acids in peptide synthesis [31][33][34][37-40].

Because the reaction of $\alpha$-hydroxy acids with $2 H$-azirin-3-amines followed by the 'direct amide cyclization' proved to be a convenient access to morpholine-2,5-diones, we intended to generalize this reaction sequence. Therefore, we carried out the reaction under similar conditions with some $\beta$-hydroxy acids in order to obtain 7-membered cyclic depsipeptides. In the present paper, we report the results of the reaction of $2 \mathrm{H}$-azirin-3-amines with 3 -hydroxy2,2-dimethylpropanoic acid (4).

\section{Results and Discussion}


2.1. Direct Amid Cyclization. - As a model $\beta$-hydroxy acid we chose 3-hydroxy-2,2dimethylpropanoic acid (4), mainly due to its commercial availability and its previous use in this type of reactions [26][27]. The linear dipeptides 6 were prepared by the standard procedure [26] of coupling 4 with the corresponding $2 H$-azirin-3-amine (5a or $\mathbf{5 b}$; $c f$. [31] and refs. cit. therein), to yield $\mathbf{6 a}$ and $\mathbf{6 b}$, respectively, in excellent yields and without side products (Scheme 2).

Scheme 2

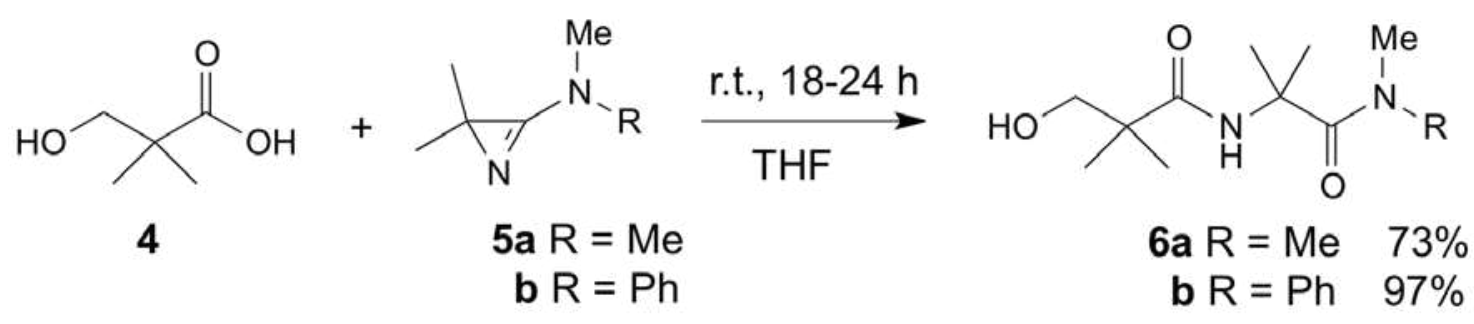

Although the general protocol proposed $\mathrm{MeCN}$ as a solvent [26], THF turned out to be a better solvent in this particular case. In addition to the spectroscopic characterization of $\mathbf{6 a}$ and $\mathbf{6 b}$ ( $c f$. [27] ), their structures were established by X-ray crystallography (Fig. 1).

a)

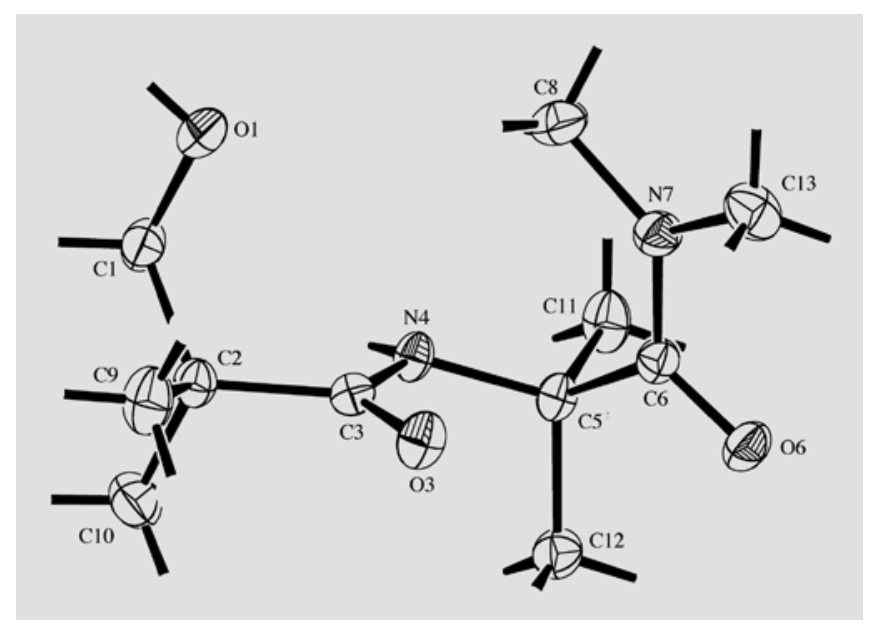


b)

Fig. 1. ORTEP-Plots [41] of the molecular structures of a) 6a and b) one of the two symmetry-independent molecules of $\mathbf{6 b}$ (arbitrary numbering of the atoms; $50 \%$ probability ellipsoids).

The conformations of the backbones of $\mathbf{6 a}$ and $\mathbf{6 b}$ are very similar, with the exception of the orientation of the $\mathrm{OH}$ group. In $\mathbf{6 a}$, the $\mathrm{NH}$ group forms an intermolecular $\mathrm{H}$-bond with its adjacent amide O-atom from a neighboring molecule $(\mathrm{N}(4) \cdots \mathrm{O}(6 ”)$ 2.885(1) $\AA$; $\mathrm{N}(4)$ $\left.\mathrm{H}^{\cdots} \mathrm{O}\left(6^{\prime \prime}\right) 161(1)^{\circ}\right)$. This interaction links the molecules into extended chains which run parallel to the $y$-axis and have a graph set motif [42] of $\mathrm{C}(5)$. The $\mathrm{OH}$ group forms an intermolecular $\mathrm{H}$-bond with its adjacent amide $\mathrm{O}$-atom from a different neighboring molecule $\left(\mathrm{O}(1)^{\cdots} \mathrm{O}\left(3^{\prime}\right) 2.770(2) \AA ; \mathrm{O}(1)-\mathrm{H}^{\cdots} \mathrm{O}\left(3^{\prime}\right) 169(2)^{\circ}\right)$ and thereby also links the molecules into infinite chains which run parallel to the $y$-axis and have a graph set motif of $\mathrm{C}(6)$. The combination of the intermolecular interactions links the molecules into a two-dimensional network which runs parallel to the $x y$-plane. 
In the case of $\mathbf{6 b}$, there are two symmetry-independent molecules in the asymmetric unit and they have almost identical conformations. The $\mathrm{NH}$ group in each molecule forms an intramolecular H-bond with the $\mathrm{OH}$ group (e.g. $\mathrm{N}(4)^{\cdots} \mathrm{O}(7) 2.728(2) \AA ̊ \mathrm{~N}(4)-\mathrm{H}^{\cdots} \mathrm{O}(7) 142(1)^{\mathrm{o}}$ in molecule A) to yield a six-membered loop with a graph set motif of $\mathrm{S}(6)$. The $\mathrm{OH}$ group of molecule A forms an intermolecular $\mathrm{H}$-bond with the primary amide O-atom of molecule B $\left(\mathrm{O}(7)+\mathrm{H} \mathrm{O}\left(25^{\prime}\right) 2.684(1) \AA{ }^{\prime} ; \mathrm{O}(7)-\mathrm{H}+\mathrm{H} \mathrm{O}\left(25^{\prime}\right) 173(2)^{\circ}\right)$, while the $\mathrm{OH}$ group of molecule $\mathrm{B}$ has a similar interaction with a different molecule A $(\mathrm{O}(27)$ HO(5") 2.692(1) $\AA$; $\mathrm{O}(27)-\mathrm{H}+\mathrm{O}(5$ ") $\left.174(2)^{\circ}\right)$. These interactions link the molecules into infinite chains in which both symmetryindependent molecules are incorporated in an alternating chains run parallel to the $y$-axis and have a binary graph set motif of $\mathrm{C}_{2}^{2}(12)$.

The dipeptide $\mathbf{6 b}$, was subjected to the reaction conditions of the 'direct amide cycliszation', i.e. dry $\mathrm{HCl}$ gas was bubbled through a toluene suspension of $\mathbf{6 b}$ at $100^{\circ}$. It was expected that 6b would react in an analogous manner to the amide 7, which gave 3,3,6,6tetramethylmorpholine-2,5-dione (8) in up to 60\% yield [43] (Scheme 3). Surprisingly, only the dimer of the expected 7-membered ring 9, namely the 14-membered 3,3,6,6,10,10,13,13octamethyl-1,8-dioxa-4,11-diazacyclotetradecane-2,5,9,12-tetraone (10), was formed in 72\% yield (Scheme 3).

\section{Scheme 3}


<smiles>[R]N(C)C(=O)C(C)(C)NC(=O)C(C)(C)O</smiles>

$7 \mathrm{a} R=\mathrm{Me}$

b $\mathrm{R}=\mathrm{Ph}$

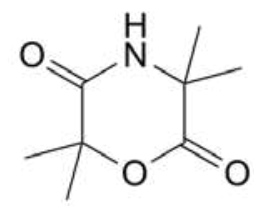

8<smiles>CC1(C)COC(=O)C(C)(C)NC1=O</smiles>

9<smiles>[R]N(C)C(=O)C(C)(C)NC(=O)C(C)(C)CO</smiles>

$\mathrm{HCl}$ gas, $100^{\circ}$, Toluene

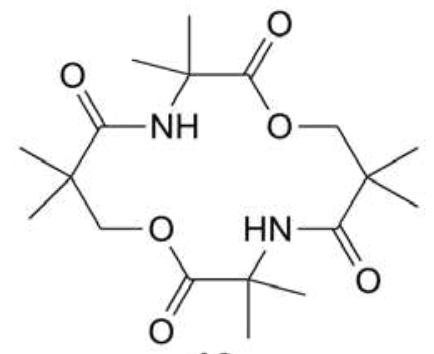

10

b $\mathrm{R}=\mathrm{Ph}$

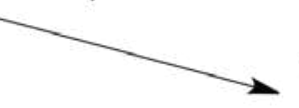

The ${ }^{1} \mathrm{H}-\mathrm{NMR}$ spectrum of $\mathbf{1 0}$ showed no signal for $\mathrm{OH}$ groups and confirmed the presence of NH groups. Two singlets for Me groups and a singlet for $\mathrm{CH}_{2}$ were also clearly distinguished. The ${ }^{13} \mathrm{C}-\mathrm{NMR}$ spectra showed the presence of two $\mathrm{C}=\mathrm{O}$ groups $(174.3$ and $178.2 \mathrm{ppm}$ in ( $\left.\mathrm{D}_{6}\right)$ DMSO), which was further confirmed by the IR spectrum $\left(\mathrm{KBr} ; 1723\right.$ and $\left.1673 \mathrm{~cm}^{-1}\right)$. Furthermore, the ${ }^{13} \mathrm{C}-\mathrm{NMR}$ spectrum indicated two different types of $\mathrm{Me}_{2} \mathrm{C}$ groups, in addition to a $\mathrm{OCH}_{2}$ group. With this set of data, the distinction between the monomeric lactone 9 and the dimer $\mathbf{1 0}$ was not possible. But the mass spectra (CI and ESI mode) indicated a molecular weight of 370 , which corresponds to the 14-membered depsipeptide $\mathbf{1 0}$. Finally its structure was confirmed by X-ray crystallography ( Fig. 2). 


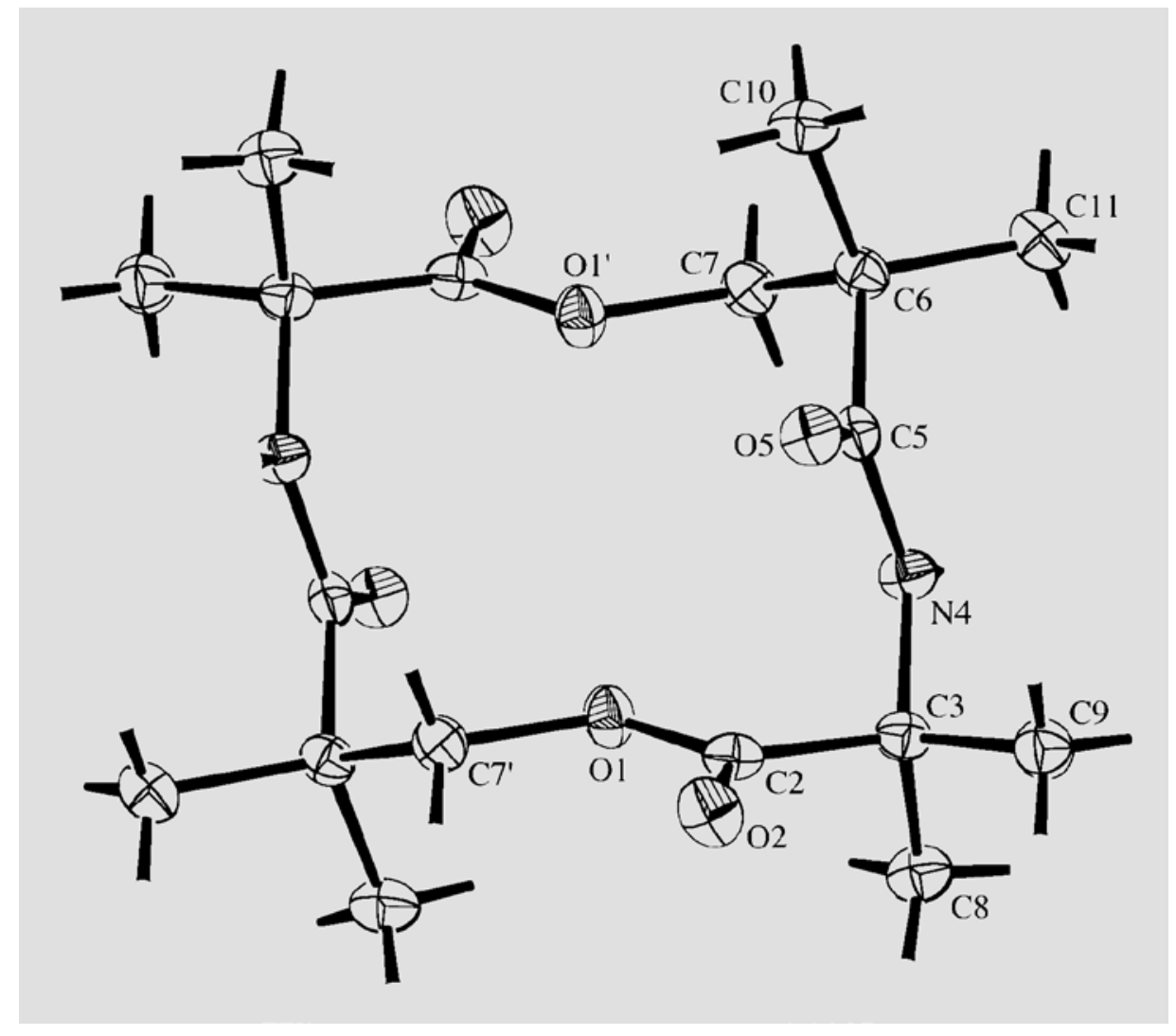

Fig. 2. ORTEP-Plot [41] of the molecular structure of $\mathbf{1 0}$ (arbitrary numbering of the atoms; $50 \%$ probability ellipsoids).

The molecule sits across a crystallographic center of inversion. The symmetry-unique NH group forms a very weak intermolecular $\mathrm{H}$-bond with the amide $\mathrm{O}$-atom from the same amide

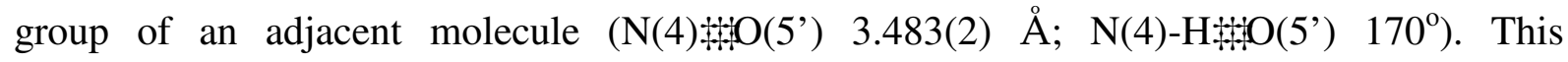
interaction links the molecules into extended chains which run parallel to the $z$-axis and have a graph set motif of $\mathrm{C}(4)$. The other amide group in the molecule participates in an identical intermolecular interaction of necessity because of the centrosymmetric nature of the molecule. The chains thereby formed also run parallel to the $z$-axis but in the opposite direction. The molecules themselves bridge adjacent chains, so that the combination of both interactions links the molecules into two-dimensional networks which lie parallel to the (100) plane. The 
cross-linking of the chains also builds H-bonded loops involving four molecules and yields the graph set motif of $\mathrm{R}_{4}^{4}(26)$.

With the aim of obtaining the 7-membered, monomeric cyclodepsipeptide 9 (Scheme 3), we repeated the reaction with varying concentrations of the starting material $\mathbf{6 b}$ and different reaction times. However, under all conditions $\mathbf{1 0}$ was formed as the only product, although in variable yield. Thus, the maximum yield of $72 \%$ was obtained at a concentration of $20 \mathrm{mM}$, whereas with a concentration of $2 \mathrm{mM}$ the yield dropped to $35 \%$, and at a concentration of 40 $\mathrm{mM}$ the yield was only $61 \%$.

The rate determining step of the 'direct amide cyclization' is believed to be the formation of the oxazolone ring (see Scheme 1), a process favored by the precipitation of the corresponding ammonium salt. Thus the formation of the lactone is a function of the salt's solubility in toluene $^{2)}$. As a result, $N, N$-dimethylamides of type $6 \mathbf{a}$ should react more easily than $N$-methyl$N$-phenylamides like $\mathbf{6 b}$ under the conditions of the 'direct amide cyclization', because the initially formed $\mathrm{Me}_{2} \mathrm{NH} . \mathrm{HCl}$ is less soluble in toluene than $\mathrm{Ph}(\mathrm{Me}) \mathrm{NH} . \mathrm{HCl}$.

Therefore, we also used 6a as a starting material. The cyclization with $\mathrm{HCl}$ gas in toluene at $100^{\circ}$ gave again the product 10 . The lower yield (32\%) is mainly caused by purification difficulties (see experimental part).

\footnotetext{
${ }^{2}$ ) It has been shown previously, that the formation of a 16-membered cyclic depsipeptide, which in toluene (heterogeneous conditions) was obtained in $60 \%$ yield, does not occur in homogeneous solution in DMF [26].
} 
In order to prepare $\mathbf{1 0}$ by a specific synthesis, we synthesized the open chain precursor, the linear depsipeptide 11, according to standard procedures, starting from the commercially available methyl ester 12. After protection of the $\mathrm{OH}$ group by benzylation to give $\mathbf{1 3}$ and deprotection of the carboxyl group, the intermediate $\mathbf{1 4}$ was coupled with $\mathbf{5 b}$ to yield the diamide 15. The product of its acid-catalyzed hydrolysis $\mathbf{1 6}$ was coupled with $\mathbf{6 b}$ to give $\mathbf{1 7}$, which after deprotection gave 11 in a total yield of 24\% (Scheme 4). Crystallization from a mixture of $\mathrm{CH}_{2} \mathrm{Cl}_{2}$, i-PrOH, and hexane gave crystals, which were suitable for an $\mathrm{X}$-ray crystal-structure determination (Fig. 3).

Scheme 4

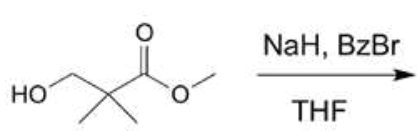

12

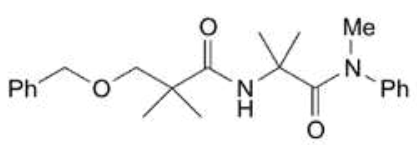

15

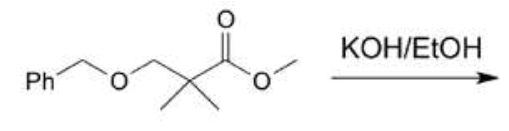

13

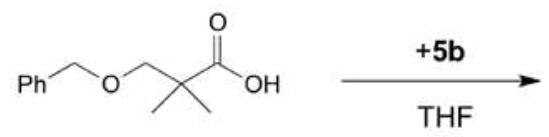

14

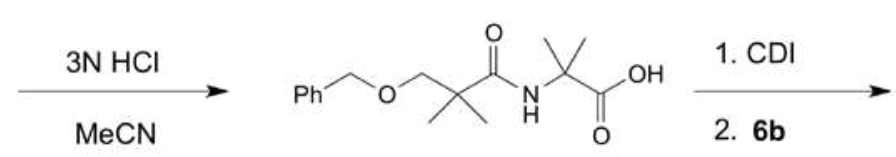

16

3. Na Imidazolid<smiles>CN(C(=O)C(C)(C)NC(=O)C(C)(C)COC(=O)C(C)(C)NC(=O)C(C)(C)COCc1ccccc1)c1ccccc1</smiles>

17

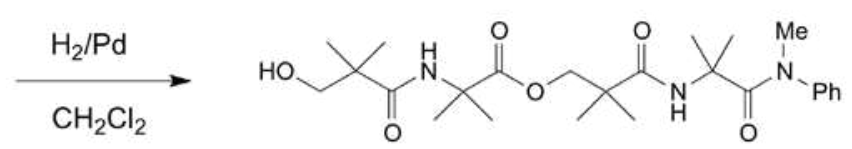

11

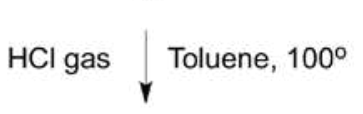

10 


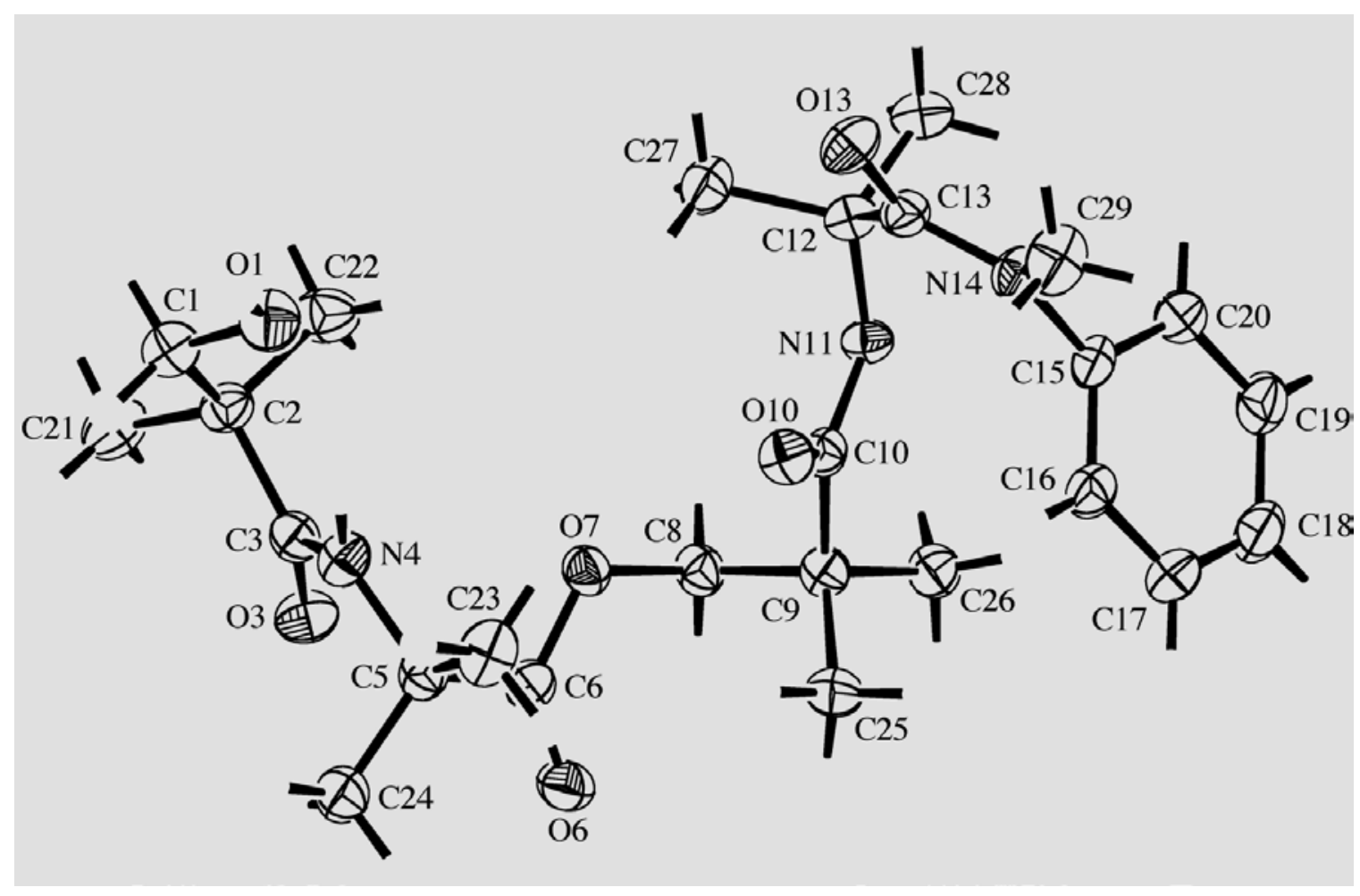

Fig. 3. ORTEP-Plot [41] of the molecular structure of $\mathbf{1 1}$ (arbitrary numbering of the atoms; $50 \%$ probability ellipsoids).

Although the molecule is achiral, the crystal structure is chiral. The absolute structure has not been determined and was defined arbitrarily. The amide $\mathrm{NH}$ group closest to the $\mathrm{OH}$ group

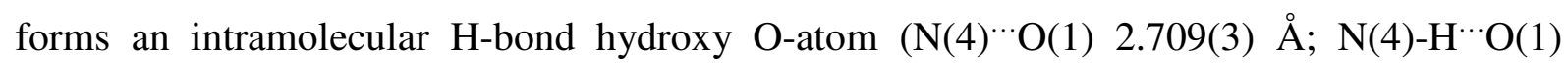
$\left.135(3)^{\circ}\right)$. This gives rise to a six-membered loop with a graph set motif of $\mathrm{S}(6)$, analogous to compound $\mathbf{6 b}$ (Fig. 1). The other amide group forms an intermolecular H-bond with the adjacent amide O-atom from a neighboring molecule (N(11) ${ }^{\cdots} \mathrm{O}\left(13^{\prime \prime}\right.$ ) 2.932(3) $\AA$; $\mathrm{N}(11)$ $\left.\mathrm{H}^{\cdots} \mathrm{O}\left(13^{\prime \prime}\right) 155(3)^{\circ}\right)$. This interaction links the molecules into infinite chains which run parallel to the $y$-axis and have a graph set motif of $\mathrm{C}(5)$. The $\mathrm{OH}$ group forms an intermolecular H-bond with its adjacent amide O-atom from a different neighboring molecule $\left(\mathrm{O}(1)^{\cdots} \mathrm{O}\left(3^{\prime}\right) 2.655(3) \AA\right.$; $\left.\mathrm{O}(1)-\mathrm{H}^{\cdots} \mathrm{O}\left(3^{\prime}\right) 158(4)^{\circ}\right)$ and thereby also links the molecules into infinite chains which run parallel to the $y$-axis and have a graph set motif of $\mathrm{C}(6)$. The 
combination of intermolecular interactions links the molecules into a two-dimensional network which runs parallel to the $y z$-plane.

Compound 11 was subjected to cyclization under the standard conditions of the 'direct amide cyclization'. Once more, the 14-membered cyclodepsipeptide 10 was the only product that could be isolated, with the moderate yield of $42 \%$.

2.2. Other lactonisation methods. - After all attempts to obtain the 7-membered ring 9 by the 'direct amide cyclization' failed, even after a ten-fold dilution of the reaction mixture, we were faced with a number of classical lactonisation options, starting mainly with the corresponding hydroxy acid 18, which was obtained easily from either of the amides $\mathbf{6}$ by hydrolysis in an acidic medium. The crystal-structure of $\mathbf{1 8}$ is shown in Fig. 4.

a)

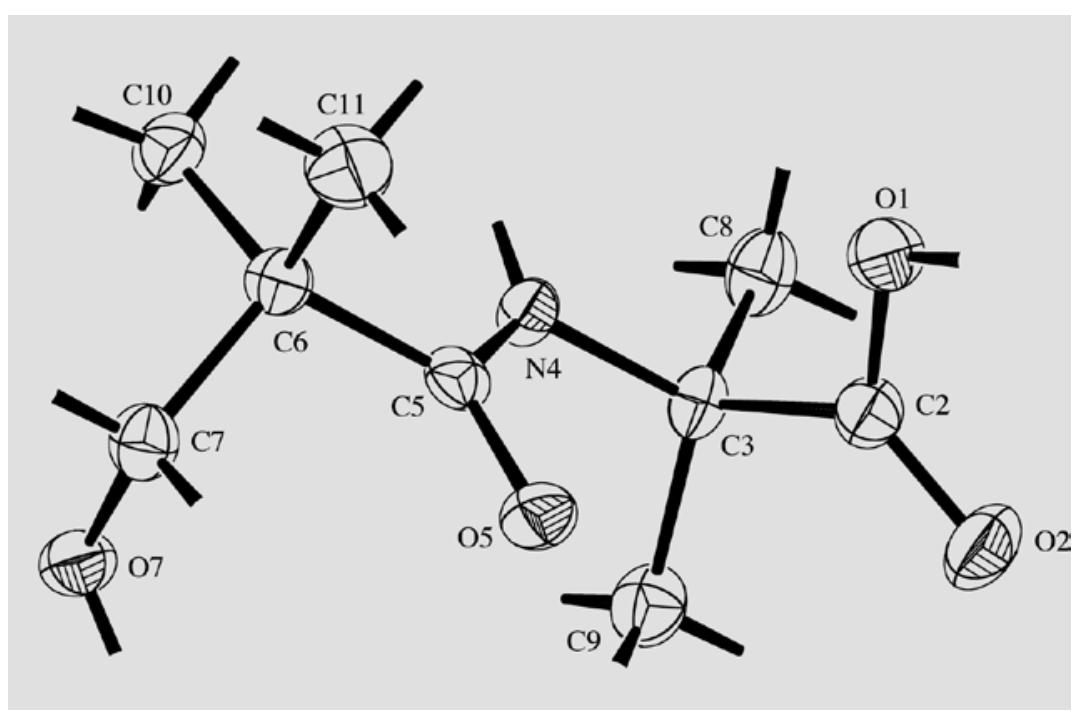

b) 


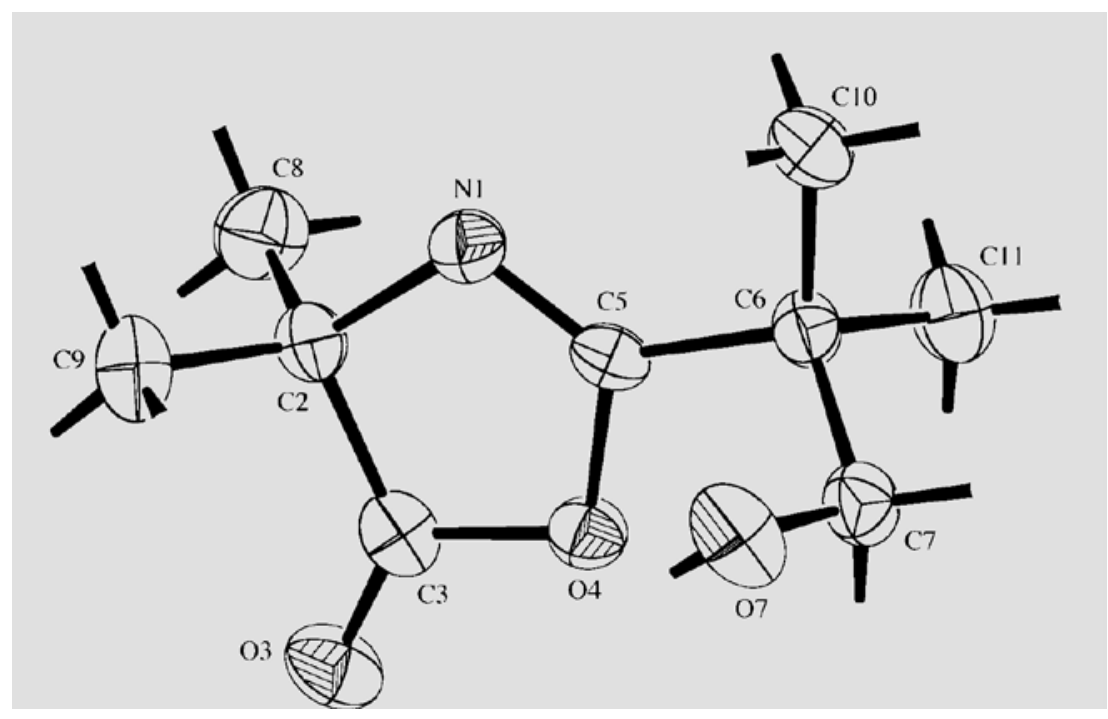

Fig. 4. ORTEP-Plots [41] of the molecular structures of a) $\mathbf{1 8}$ and b) one of the two symmetryindependent molecules of $\mathbf{1 9}$ (arbitrary numbering of the atoms; 50\% probability ellipsoids).

The NH group forms an intermolecular H-bond with the O-atom of the hydroxy group of a

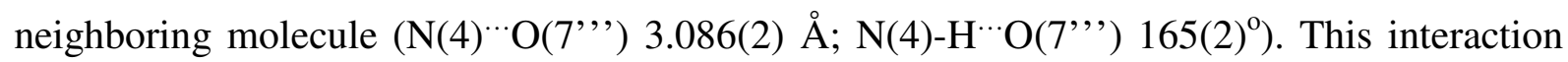
links the molecules into extended chains which run parallel to the $y$-axis and have a graph set motif of $\mathrm{C}(6)$. The $\mathrm{OH}$ group forms an intermolecular $\mathrm{H}$-bond with $\mathrm{C}=\mathrm{O}$ of the $\mathrm{COOH}$ group from a different neighboring molecule $\left(\mathrm{O}(7)^{\cdots} \mathrm{O}\left(2^{\prime \prime}\right)\right.$ 2.746(2) $\AA$; $\left.\left.\mathrm{O}(7)-\mathrm{H}^{\cdots} \mathrm{O}\left(2^{\prime \prime}\right)^{\prime}\right) 170(2)^{\circ}\right)$. This interaction also links the molecules into infinite chains which run parallel to the $y$-axis and have a graph set motif of $\mathrm{C}(9)$. The $\mathrm{OH}$ group of $\mathrm{COOH}$ forms an intermolecular H-bond with the amide O-atom of a third neighboring molecule $\left(\mathrm{O}(1)^{\cdots} \mathrm{O}\left(5^{\prime}\right)\right.$ 2.606(2) $\AA$; $\mathrm{O}(1)$ $\left.\mathrm{H}^{\cdots} \mathrm{O}\left(5^{\prime}\right) 172(2)^{\circ}\right)$. Again, this interaction links the molecules into infinite chains which run parallel to the $y$-axis and have a graph set motif of $\mathrm{C}(7)$. The combination of all H-bonding interactions links the molecules into two-dimensional network which lies parallel to the $x y$ plane. 
The variety of lactonization methods, is enormous, and we could try only a few of them. As starting point, we used the review by Nicolaou [44] where the classical methods of Yamaguchi [45], Corey-Nicolaou [46], and Mukaiyama [47] are mentioned. Unfortunately, none of the above reactions yielded the desired product, and the only products obtained were the activated acid derivates, namely the Yamaguchi mixed anhydride and the Corey active ester, respectively. Some modern variations of these methods [48] were also tried, but they failed to give the desired product too. The most common cyclization methods, using DCC or its water-soluble derivatives and analogues, gave as the only product 2-(2-hydroxy-1,1dimethylethyl)-4,4-dimethyloxazol-5(4H)-one (19) in 36\% yield (Scheme 5). This is the postulated intermediate of the prospected 'direct amide cyclization' $\mathbf{6} \rightarrow \mathbf{9}$. Even after addition of 4-(dimethylamino)pyridine (DMAP) to a mixture of $\mathbf{1 8}$ and DCC, a procedure known to be suitable for the synthesis of medium sized lactones [49], the reaction path did not change and 19 was isolated as the only product, although in moderate yield.

In general, 1,3-oxazol-5(4H)-ones are reactive species; in the case of 19, the gem-dimethyl group seems to stabilize it, so that it could be isolated in crystalline form. In the IR spectrum (KBr), 19 showed a characteristic strong $\mathrm{C}=\mathrm{O}$ absorption at $1836 \mathrm{~cm}^{-1}$ and in the ${ }^{13} \mathrm{C}-\mathrm{NMR}$ spectrum, the singlets for $\mathrm{C}=\mathrm{O}$ and $\mathrm{C}=\mathrm{N}$ appeared at 182.8 and $166.6 \mathrm{ppm}$, respectively. The structure of 19 was established by X-ray crystallography (Fig. 4).

Scheme 5

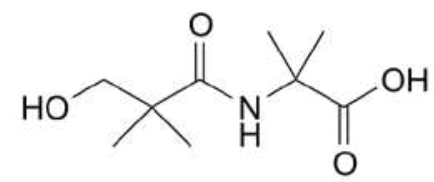

18

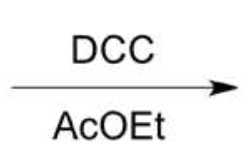

AcOEt 
The asymmetric unit contains two symmetry-independent molecules, whose conformations differ only in the orientation of the $\mathrm{OH}$ group. The $\mathrm{OH}$ group of molecule $\mathrm{A}$ forms an intermolecular H-bond with the N-atom of molecule B $\left(\mathrm{O}(7)^{\cdots} \mathrm{N}\left(21^{\prime}\right)\right.$ 2.891(2) $\AA$; $\mathrm{O}(7)$ $\left.\mathrm{H}^{\cdots \cdots} \mathrm{N}\left(21^{\prime}\right) 159(3)^{\circ}\right)$. In turn, molecule B has an identical interaction with another molecule A. These interactions link the molecules into extended parallel to the $y$-axis and have a graph set motif [42] of $\mathrm{C}_{2}^{2}(12)$.

As $\mathbf{1 9}$ is expected to be the intermediate in the 'direct amide cyclization' $\mathbf{6} \rightarrow \mathbf{9}$, we attempted to transform 19 to the depsipeptide in polar, aprotic solvents (AcOEt, $\mathrm{MeCN}$ ), but all attempts failed. After two days of heating 19 under reflux, only the starting material was isolated. Another way of converting 19 to the depsipeptide 9 was the 'direct amide cyclization'. This reaction yielded again only product $\mathbf{1 0}$ in excellent yield (86\%, Scheme 6).

\section{Scheme 6}

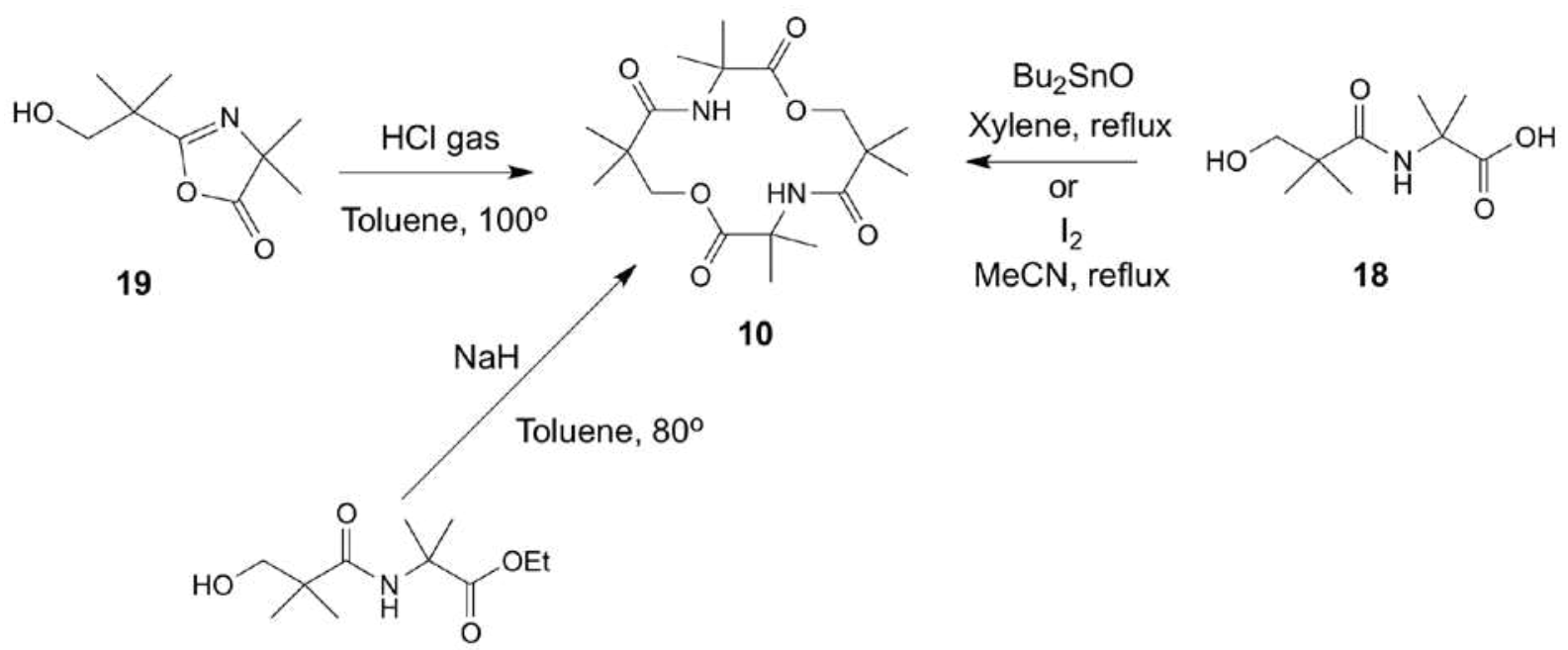


The next step we took on the way to the synthesis of the 7-membered 9 was to try out some reactions involving salts of metals, such as Sb [50], Sn [51], Ag [52], Sc [53] and Ru [54], known to catalyze the formation of small and medium sized lactones. Most of these attempts failed in the case of $\mathbf{1 8}$, and only few led to a definite product, namely once more the dimeric cyclodepsipeptide $\mathbf{1 0}$ (Scheme 6). Surprisingly, the reaction with $\mathrm{I}_{2}$ in boiling $\mathrm{MeCN}$, which was initially used to cyclize terpene-like hydroxy acids [55], gave again the 14-membered ring 10 in moderate yield (Scheme 6). Recently, Richard et al. have reported the synthesis of 7-membered lactones, containing an amino group in their basic structure, by treatment of the corresponding hydroxy esters with $\mathrm{NaH}$ in a toluene suspension [56]. Therefore, we treated the ester 20 under the same conditions. To our disappointment, this reaction yielded again the dimeric compound $\mathbf{1 0}$ as the sole product.

The discrepancy between the reactions of 6-hydroxy-4-azahexanoic esters [56] and $\mathbf{6}$ is very surprising. One of the possible reasons for the failure of this method in the case of $\mathbf{6}$ could lie in the presence of the amide bond and its rigidity. With the aim of proving this hypothesis, the ester analogue of the amide 6, i.e. the diester 22, was synthesized in the same way as compound $\mathbf{1 1}$ (Scheme 7).

\section{Scheme 7}




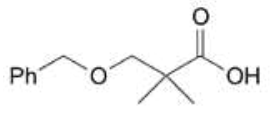

14

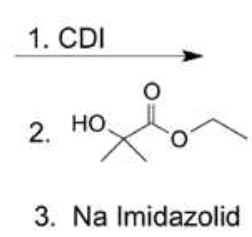

3. Na Imidazolid

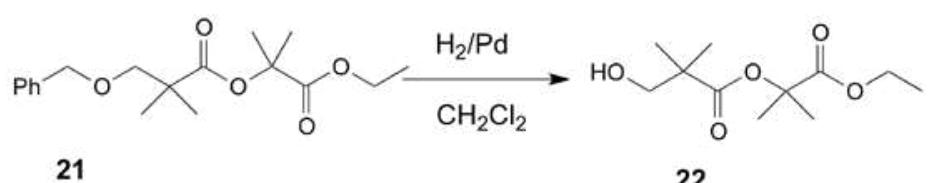

22
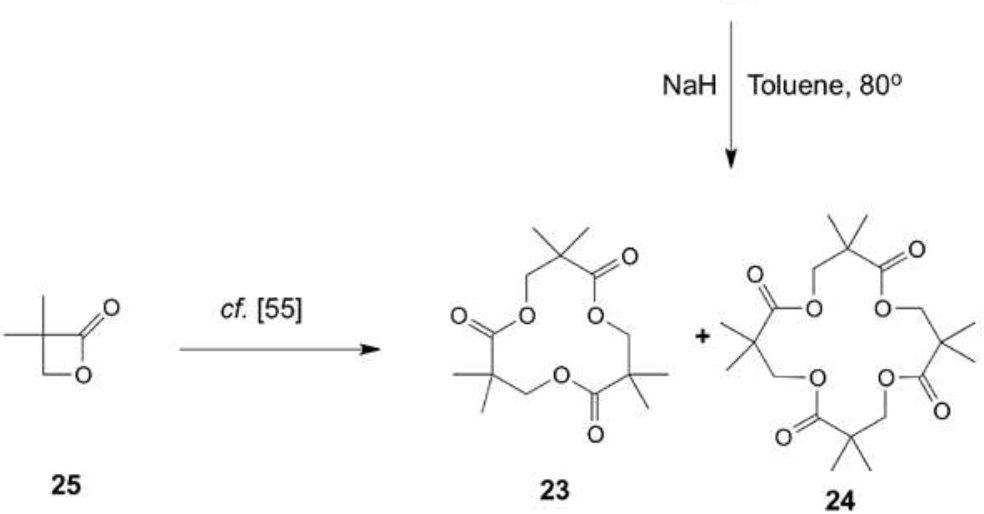

Subjecting compound $\mathbf{2 2}$ to the reaction conditions described in [56] led to a mixture of products, among which the tri- and tetralactones $\mathbf{2 3}$ and $\mathbf{2 4}$ were isolated as the main products. None of the expected 7-membered dilactone could be detected. As an additional product, 2-hydroxyisobutyric acid was also obtained. The structures of $\mathbf{2 3}$ and $\mathbf{2 4}$, i.e. the cyclic tri- and tetramers of 3-hydroxy-2,2-dimethylpropanoic acid (4) were confirmed by Xray crystal-structure analyses (Fig. 5). It turned out that these compound are already known, and the crystal-structure of $\mathbf{2 4}$ has been published previously [57]. They have been prepared by oligomerisation of 3-hydroxy-2,2-dimethylpropionolactone $\mathbf{2 5}$. Therefore, we propose that in the reaction of $\mathbf{2 2}$ with $\mathrm{NaH}, \mathbf{2 5}$ is formed by the intramolecular nucleophilic attack of the $\mathrm{OH}$ group at the central ester group and cleavage of this ester. Then, 25 undergoes the oligomerisation. Apparently, the alternative nucleophilic attack at the terminal ester group of 22, which would lead to the 7-membered dilactone, cannot compete with the formation of the $\beta$-lactone. 
a)

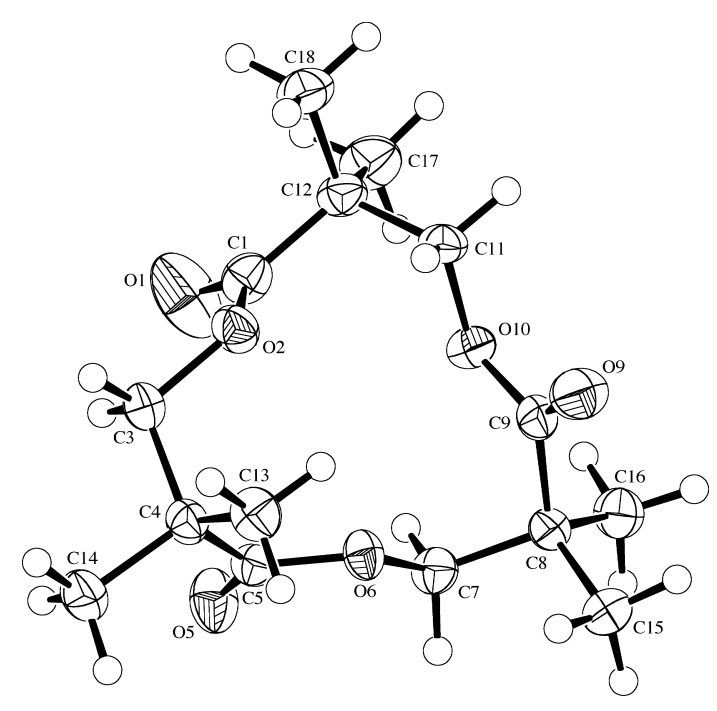

b)

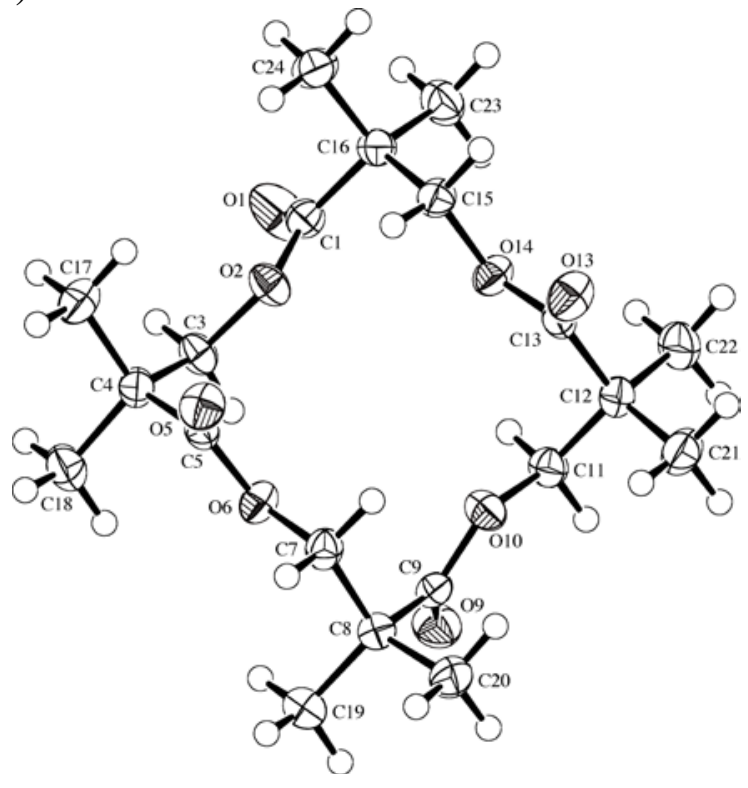

Fig. 5. ORTEP-Plots [41] of the molecular structures of a) one of the two symmetryindependent molecules of $\mathbf{2 3}$ and b) $\mathbf{2 4}$ (arbitrary numbering of the atoms; 50\% probability ellipsoids).

\section{Conclusions}

In conclusion, our attempts to prepare the 7-membered cyclic depsipeptide 3,3,6,6tetramethyl-1-oxa-4-azacycloheptane-2,5-dione (9) using the 'direct amide cyclization' starting with 3-hydroxy-2,2-dimethyl- $N$-[1-methyl-1-( $N$-methyl- $N$-phenylcarbamoyl)ethyl]propanamide (6b) failed. The only product obtained was the dimeric 14-membered cyclodepsipeptide 10, which was formed in a very good yield. Furthermore, the attempts to prepare the monomeric lactone $\mathbf{9}$ using various classical lactonisation procedures failed too, and in almost all cases $\mathbf{1 0}$ was obtained as the main product in yields of $28-72 \%$. Five different methods for the synthesis of $\mathbf{1 0}$ were developed. Despite all the variations in reaction 
conditions and the knowledge of the crystal structures of the starting materials and some of the intermediates, there is no convincing explanation for this unexpected result and additional experiments are required.

We thank the analytical units of our institute for spectra and analysis, and the Swiss National Science Fondation and F. Hoffmann-La Roche AG, Basel, for financial support.

\section{Experimental Part}

1. General. Thin-layer chromatography (TLC): Merck TLC aluminium sheets, silica gel 60 $F_{254 .}$ Prep. TLC: Merck PLC plates (glass), silica gel $60 F_{254}, 2 \mathrm{~mm}$ and 40-63 $\mu \mathrm{m}$. Flash chromatography (CC): Uetikon-Chemie 'Chromatographiegel' C-560. M.p.: Büchi 540 apparatus, uncorrected. IR Spectra: Perkin-Elmer Spectrum one spectrometer; in $\mathrm{KBr}$, unless otherwise stated, absorption bands in $\mathrm{cm}^{-1} .{ }^{1} \mathrm{H}-\mathrm{NMR}(300 \mathrm{MHz})$ and ${ }^{13} \mathrm{C}-\mathrm{NMR}(75.5 \mathrm{MHz})$ spectra: Bruker $A R X-300$ instrument; in $\mathrm{CDCl}_{3}$ at $300 \mathrm{~K}$; TMS as internal standard, unless otherwise stated; $\delta$ in ppm, coupling constants $J$ in Hz. HSQC and HMBC spectra: Bruker DRX-600 instrument; ${ }^{1} \mathrm{H}-\mathrm{NMR}(600 \mathrm{MHz})$ and ${ }^{13} \mathrm{C}-\mathrm{NMR}(150 \mathrm{MHz})$. Mass spectrometry (MS): Finnigan MAT-90 for electron impact ionization (EI), Finnigan SSQ-700 for chemical ionization $\left(\mathrm{CI}\right.$, with $\mathrm{NH}_{3}$ ) and electrospray ionization (ESI, in $\mathrm{MeOH}+\mathrm{Na}$ ), unless otherwise stated.

2. Starting materials. 2,2,N,N-Tetramethyl- $\mathrm{N}$-phenyl-2H-azirin-3-amine (5a) and 2,2,Ntrimethyl- $\mathrm{N}$-phenyl-2H-azirin-3-amine (5b) were prepared according to standard procedures ( $c f$. [31] and refs. cited therein). All other products used were commercially available.

\section{Coupling with $2 \mathrm{H}-$ Azirin-3-amines.}


N-[1-(Dimethylcarbamoyl)-1-methylethyl]-3-hydroxy-2,2-dimethylpropanamide (6a). To a soln. of 3-hydroxy-2,2-dimethylpropanoic acid (4; $806 \mathrm{mg}, 6.84 \mathrm{mmol})$ in dry THF (5ml), 5a $(1.231 \mathrm{~g}, 7.52 \mathrm{mmol})$ was added dropwise. The mixture was stirred at r.t. for $36 \mathrm{~h}$, the solvent was evaporated, and the remaining solid was purified by $\mathrm{CC}\left(\mathrm{SiO}_{2}, \mathrm{MeOH} / \mathrm{CH}_{2} \mathrm{Cl}_{2} 1: 10\right)$ and dried in h.v. Yield: $1.200 \mathrm{~g}(76 \%)$ of 6a. Pale yellow crystals. M.p. 126.2-127.4 ${ }^{\mathrm{o}}{ }^{1} \mathrm{H}-\mathrm{NMR}$ : 1.10, $1.33\left(2 s, 2 \mathrm{Me}_{2} \mathrm{C}\right) ; 3.22\left(s, \mathrm{Me}_{2} \mathrm{~N}\right) ; 3.46\left(s, \mathrm{CH}_{2} \mathrm{O}\right) ; 3.90$ (br. $\left.s, \mathrm{OH}\right) ; 6.79$ (br. $\left.s, \mathrm{NH}\right)$. ${ }^{13} \mathrm{C}-\mathrm{NMR}: 22.1,26.3\left(2 q, 2 \mathrm{Me}_{2} \mathrm{C}\right) ; 41.6\left(s, \mathrm{Me}_{2} C\right) ; 42.4\left(q, \mathrm{Me}_{2} \mathrm{~N}\right) ; 58.7\left(s, \mathrm{Me}_{2} C\right) ; 70.4(t$, $\left.\mathrm{CH}_{2} \mathrm{O}\right) ; 174.1,177.2(2 s, 2 \mathrm{CO})$. CI-MS: $231\left(68,[M+1]^{+}\right), 186(100)$.

\section{3-Hydroxy-2,2-dimethyl-N-[1-methyl-1-(N-methyl-N-phenylcarbamoyl)ethyl]propanamide} (6b). To a soln. of 4 (806 mg, $6.84 \mathrm{mmol})$ in dry THF (5ml), $5 \mathbf{b}(1.309 \mathrm{~g}, 7.52 \mathrm{mmol})$ was added dropwise. The mixture was stirred at r.t. for $24 \mathrm{~h}$, the solvent was evaporated and the remaining solid was purified by $\mathrm{CC}\left(\mathrm{SiO}_{2}, \mathrm{MeOH} / \mathrm{CH}_{2} \mathrm{Cl}_{2}\right.$ 1:20) and dried in h.v. Yield: 1.86 g (93\%) of 6b. White solid. M.p.102.8-103.3 ${ }^{\circ}$ ([27]: 103.4-104 $\left.{ }^{\circ}\right) .{ }^{1} \mathrm{H}-\mathrm{NMR}: 1.11,1.38$ (2s, 2 $\mathrm{Me}_{2} \mathrm{C}$ ); $3.28(s, \mathrm{MeN}) ; 3.44\left(s, \mathrm{CH}_{2} \mathrm{O}\right) ; 3.90$ (br. $\left.s, \mathrm{OH}\right) ; 6.77$ (br. $\left.s, \mathrm{NH}\right) ; 7.25-7.45$ (m, 5

arom. H). ${ }^{13} \mathrm{C}-\mathrm{NMR}: 22.2,26.3\left(2 q, 2 \mathrm{Me}_{2} \mathrm{C}\right) ; 41.6\left(s, \mathrm{Me}_{2} C\right) ; 43.6(q, \mathrm{MeN}) ; 58.7\left(s, \mathrm{Me}_{2} C\right)$; $70.4\left(t, \mathrm{CH}_{2} \mathrm{O}\right) ; 128.2(d, 1$ arom. $\mathrm{CH}) ; 128.4,129.5$ (2d, 4 arom. $\left.\mathrm{CH}\right) ; 144.4(s, 1$ arom. $\mathrm{C})$; 174.1, $177.2(2 s, 2 \mathrm{CO})$.

\section{Cyclizations to 3,3,6,6,10,10,13,13-Octamethyl-1,8-dioxa-4,11-diazacyclotetradecane-} 2,5,9,12-tetraone $(\mathbf{1 0})$.

4.1. Direct Amide Cyclisations. Procedure A. A suspension of $\mathbf{6 b}(584 \mathrm{mg}, 2 \mathrm{mmol})$ in dry toluene $(100 \mathrm{ml})$ was heated to $100^{\circ}$, and $\mathrm{HCl}$ gas was bubbled through the suspension for 7 min. Then, the mixture was let to cool to r.t. while bubbling $\mathrm{N}_{2}$ through it ( $c a .20 \mathrm{~min}$ ). The solvent was evaporated, the white residue was washed with $3 \times 15 \mathrm{ml}$ of $\mathrm{CH}_{2} \mathrm{Cl}_{2}$ and dried in 
h.v. Yield: $267 \mathrm{mg}$ (72\%) of 10. White powder. M.p. 299.2-300.4 ${ }^{\circ}$ IR: 3393vs (NH), 2990s, 2977s, 2935m, 1723vs (C=O), 1673vs (C=O), 1523vs, 1171vs (C-O). ${ }^{1} \mathrm{H}-\mathrm{NMR}\left(\left(\mathrm{D}_{7}\right) \mathrm{DMF}\right)$ : 1.12, $1.40\left(2 s, 2 \mathrm{Me}_{2} \mathrm{C}\right.$ each $) ; 4.00\left(s, 2 \mathrm{CH}_{2} \mathrm{O}\right) ; 7.64(s, 2 \mathrm{NH}) .{ }^{13} \mathrm{C}-\mathrm{NMR}\left(\left(\mathrm{D}_{7}\right) \mathrm{DMF}\right): 22.1$, $24.6\left(2 q, 2 \mathrm{Me}_{2} \mathrm{C}\right.$ each); 41.6, $55.4\left(2 s, 2 \mathrm{Me}_{2} \mathrm{C}\right) ; 71.3\left(t, \mathrm{CH}_{2} \mathrm{O}\right) ; 174.3(s, \mathrm{C}=\mathrm{O}) .{ }^{13} \mathrm{C}-\mathrm{NMR}$ ((D $\left.\left.{ }_{6}\right) \mathrm{DMSO}\right): 20.9,23.2\left(2 q, 2 \mathrm{Me}_{2} \mathrm{C}\right.$ each); 40.4, $54.4\left(2 s, 2 \mathrm{Me}_{2} C\right) ; 70.1\left(t, \mathrm{CH}_{2} \mathrm{O}\right) ; 173.0$, $174.3(s, \mathrm{C}=\mathrm{O})$. CI-MS: $388\left(34,\left[M+\mathrm{NH}_{4}\right]^{+}\right), 371\left(100,[M+1]^{+}\right)$. ESI-MS: $393(100,[M+$ $\mathrm{Na}]^{+}$). Anal. calc. for $\mathrm{C}_{18} \mathrm{H}_{30} \mathrm{~N}_{2} \mathrm{O}_{6}$ (370.45): C 58.36, H 8.16, N 7.56; found C 57.94, H 8.18, N 7.47.

Procedure B. A suspension of $\mathbf{6 a}(230 \mathrm{mg}, 1 \mathrm{mmol})$ in dry toluene $(50 \mathrm{ml})$ was heated to $100^{\circ}$, and $\mathrm{HCl}$ gas was bubbled through the suspension for $3 \mathrm{~min}$. Then, the mixture was let to cool to r.t. while bubbling $\mathrm{N}_{2}$ through it (ca.20 min). The solvent was evaporated, the white residue was washed with $3 \times 10 \mathrm{ml}$ of $\mathrm{CH}_{2} \mathrm{Cl}_{2}$ and the remaining solid was recrystallized from MeCN to yield $60 \mathrm{mg}(32 \%)$ of $\mathbf{1 0 .}$

Procedure C. A suspension of $\mathbf{1 1}$ (see section 5, $477 \mathrm{mg}, 1 \mathrm{mmol}$ ) in dry toluene (50 ml) was heated to $100^{\circ}$, and $\mathrm{HCl}$ gas was bubbled through the suspension for $3 \mathrm{~min}$. Workup as described in Procedure A gave $92 \mathrm{mg}$ (49\%) of $\mathbf{1 0 .}$ 
4.2 Other lactonisation methods. 2-[(3-Hydroxy-2,2-dimethyl-propanoyl)amino]-2-methylpropanoic acid $(\mathbf{1 8})$. To a soln. of $\mathbf{6 b}(2.00 \mathrm{~g}, 7.35 \mathrm{mmol})$ in $\mathrm{THF}(10 \mathrm{ml}), 3 \mathrm{~N} \mathrm{HCl}(10 \mathrm{ml})$ was added dropwise at $0^{\circ}$ under constant stirring. After $8 \mathrm{~h}$ at r.t., THF was removed i.v. and the $\mathrm{H}_{2} \mathrm{O}$ phase was extracted with AcOEt $(5 \times 20 \mathrm{ml})$. The combined org. fractions were dried $\left(\mathrm{MgSO}_{4}\right)$ and the solvent evaporated. The remaining brownish crystals were washed twice with $\mathrm{Et}_{2} \mathrm{O} / \mathrm{PrOH}$ 100:1. Yield: $1.312 \mathrm{~g}$ (92\%) of 18. White crystals. M.p.142.3-143.4 ([27]: 142.8-144.0 $\left.0^{\circ}\right) .{ }^{1} \mathrm{H}-\mathrm{NMR}\left(\left(\mathrm{D}_{6}\right) \mathrm{DMSO}\right): 1.00,1.35\left(2 s, 2 \mathrm{Me}_{2} \mathrm{C}\right) ; 3.36\left(s, \mathrm{CH}_{2} \mathrm{O}\right) ; 5.00$ (br. $s, \mathrm{OH}) ; 7.52$ (br. $s, \mathrm{NH}) ; 12.12$ (br. $s, \mathrm{COOH}$ ).

Procedure D. A soln. of $\mathbf{1 8}(205 \mathrm{mg}, 1 \mathrm{mmol})$ and $\mathrm{I}_{2}(15 \mathrm{mg}, 0.06 \mathrm{mmol})$ in dry MeCN (15 ml) was heated to reflux for $3 \mathrm{~d}$. After evaporation of the solvent, the residue was washed with $5 \% \mathrm{Na}_{2} \mathrm{~S}_{2} \mathrm{O}_{3}$ soln. and extracted with AcOEt, and the combined org. fractions were dried $\left(\mathrm{MgSO}_{4}\right)$. Purification by CC yielded $89 \mathrm{mg}(49 \%)$ of $\mathbf{1 0}$ as a white powder. Procedure E. A soln. of 18 (103 mg, $0.5 \mathrm{mmol})$ and $\mathrm{Bu}_{2} \mathrm{SnO}(25 \mathrm{mg}, 0.1 \mathrm{mmol})$ in dry xylene $(25 \mathrm{ml})$ was heated under reflux for $2 \mathrm{~d}$ in a Dean-Stark apparatus $\left(\mathrm{N}_{2}\right.$-atmosphere). Then, the solvent was evaporated i.v., the solid residue was washed with $\mathrm{Et}_{2} \mathrm{O}(2 \times 10 \mathrm{ml})$ and than with warm acetone $(5 \times 10 \mathrm{ml})$. The acetone fraction was concentrated to $5 \mathrm{ml}$, cooled and filtered to yield $36 \mathrm{mg}(38 \%)$ of $\mathbf{1 0 .}$

Ethyl 2-[(3-Hydroxy-2,2-dimethylpropanoyl)amino]-2-methylpropanoate (20). A soln. of $\mathbf{6 b}$ (584 mg, $2 \mathrm{mmol})$ in a $10 \% \mathrm{EtOH}$ soln. in toluene $(110 \mathrm{ml})$ was heated to $100^{\circ}$, and $\mathrm{HCl}$ gas was bubbled through the suspension for $7 \mathrm{~min}$. Then, the mixture was let to cool to r.t. while bubbling $\mathrm{N}_{2}$ through it (ca. $20 \mathrm{~min}$ ). The solvent was evaporated, purification by $\mathrm{CC}$ $\left(\mathrm{CH}_{2} \mathrm{Cl}_{2}\right.$ /acetone 100:1) yielded $397 \mathrm{mg}$ (86\%) of 20 as colorless oil. ${ }^{1} \mathrm{H}-\mathrm{NMR}: 1.14$ ( $s, \mathrm{Me}_{2} \mathrm{C}$ )$; 1.28\left(t, \mathrm{MeCH}_{2} \mathrm{O}\right) ; 1.43\left(s, \mathrm{Me}_{2} \mathrm{C}\right) ; 3.53\left(d, \mathrm{CH}_{2} \mathrm{OH}\right) ; 4.05\left(q, \mathrm{MeCH}_{2} \mathrm{O}\right) ; 6.79(s, \mathrm{NH}) .{ }^{13} \mathrm{C}-$ NMR: $15.6(q, \mathrm{Me}) ; 22.1,26.3\left(2 q, 2 \mathrm{Me}_{2} \mathrm{C}\right) ; 41.6\left(s, \mathrm{Me}_{2} C\right) ; 61.4\left(t, \mathrm{CH}_{2} \mathrm{O}\right) ; 69.1\left(t, C \mathrm{H}_{2} \mathrm{O}\right)$; $76.8\left(\mathrm{~s}, \mathrm{Me}_{2} C\right) ; 174.3,178.6(2 s, 2 \mathrm{CO})$. ESI-MS: $254\left(100,[M+\mathrm{Na}]^{+}\right)$. 
Procedure F. To a soln. of 20 (232 mg, $1 \mathrm{mmol})$ in dry toluene (5 ml), NaH (40 mg of a 60\% suspension in mineral oil, $1 \mathrm{mmol})$ was added slowly at $0^{\circ}$ and under constant stirring $\left(\mathrm{N}_{2}\right.$ atmosphere). After $4.5 \mathrm{~h}$ at $80^{\circ}$, the mixture was acidified with $0.1 \mathrm{~N} \mathrm{HCl}(\sim 6 \mathrm{ml})$ to $\mathrm{pH} 5$ and extracted with $\mathrm{CH}_{2} \mathrm{Cl}_{2}$ and AcOEt. The combined org. fractions were dried $\left(\mathrm{MgSO}_{4}\right)$ and evaporated i.v. The crystalline residue was washed with $\mathrm{CH}_{2} \mathrm{Cl}_{2}$ to yield $52 \mathrm{mg}(28 \%)$ of $\mathbf{1 0}$.

\section{Synthesis of 2-Methyl-2-\{[1-methyl-1-(N-methyl-N-phenylcarbamoyl)ethyl]-}

carbamoyl]propyl 2-[(3-Hydroxy-2,2-dimethyl-propanoyl)amino]-2-methylpropanoate (11). Methyl 3-Benzyloxy-2,2-dimethylpropanoate (13). To a suspension of $\mathrm{NaH}$ (440 $\mathrm{mg}$ of a $60 \%$ suspension in mineral oil, $11 \mathrm{mmol})$ in dry THF (15 ml) methyl 3-hydroxy-2,2dimethylpropanoate $(1.322 \mathrm{~g}, 10 \mathrm{mmol})$ was added dropwise at $0^{\circ}$ and under constant stirring. The reaction was stirred at r.t. for $1 \mathrm{~h}$, then benzyl bromide $(1.710 \mathrm{~g}, 10 \mathrm{mmol})$ was added. After heating under reflux for $3 \mathrm{~h}$, the mixture was cooled, washed with brine $(2 \times$ $25 \mathrm{ml}$ ), the brine fractions were extracted with AcOEt and the combined org. fractions were dried $\left(\mathrm{MgSO}_{4}\right)$. Purification by $\mathrm{CC}\left(\mathrm{SiO}_{2}\right.$, hexane/Et $\left.2 \mathrm{O} 10: 1\right)$ yielded $1.05 \mathrm{~g}(47 \%)$ of 13. Colorless oil. IR (film): 2976m, 2863m, 1736vs (C=O), 1475s, 1454s, 1363m, 1308s, 1226s, $1192 s, 1152 s(\mathrm{C}-\mathrm{O}), 1100 s(\mathrm{C}-\mathrm{O}), 1029 m, 738 m, 698 m .{ }^{1} \mathrm{H}-\mathrm{NMR}: 1.37\left(s, \mathrm{Me}_{2} \mathrm{C}\right) ; 3.62(s$, $\left.\mathrm{CH}_{2} \mathrm{O}\right) ; 3.84(s, \mathrm{MeO}) ; 4.68\left(s, \mathrm{PhCH}_{2}\right) ; 7.40-7.52$ (m, 5 arom. $\left.\mathrm{H}\right) .{ }^{13} \mathrm{C}-\mathrm{NMR}: 22.4\left(q, M e_{2} \mathrm{C}\right)$; $43.6\left(t, \mathrm{CH}_{2}\right) ; 51.7\left(s, \mathrm{Me}_{2} C\right) ; 73.1(q, \mathrm{MeO}) ; 76.9\left(t, \mathrm{PhCH}_{2}\right) ; 127.3,127.6,128.2(3 d, 5$ arom. CH); $138.4\left(s, 1\right.$ arom. C); $176.8(s, \mathrm{C}=\mathrm{O})$. EI-MS: $222\left(28, M^{+^{+}}\right), 116(26), 107(20)$, 101 (20), 91 (100), 65 (8).

3-Benzyloxy-2,2-dimethylpropanoic acid (14). To a soln. of of $\mathbf{1 3}$ (1.00 g, $4.5 \mathrm{mmol})$ in EtOH (20 ml), $8 \mathrm{ml}$ of $2 \mathrm{~N} \mathrm{KOH}$ were added at $0^{\circ}$. After $1 \mathrm{~h}$ stirring at r.t., the org. solvent was evaporated i.v., the remaining soln. was acidified with $1 \mathrm{~N} \mathrm{HCl}$ to $\mathrm{pH} 1$ and extracted with 
$\mathrm{Et}_{2} \mathrm{O}$. The org. fractions were dried $\left(\mathrm{MgSO}_{4}\right)$ and evaporated i.v. The residue was recrystallized from hexane. Yield: $830 \mathrm{mg}(88 \%)$ of 14. White crystals. M.p. 62.1-63.8 ${ }^{\circ}$ IR: 2975m, 2861m, 1707vs (C=O), 1454s, 1364m, 1163w, 1100s (C-O), 738m, 698m. ${ }^{1} \mathrm{H}-\mathrm{NMR}$ ((D $)$ DMSO): $1.07\left(s, \mathrm{Me}_{2} \mathrm{C}\right) ; 3.42\left(s, \mathrm{CH}_{2} \mathrm{O}\right) ; 4.49\left(s, \mathrm{PhCH}_{2}\right) ; 7.25-7.42$ (m, 5 arom. $\left.\mathrm{H}\right)$; $12.21(s, \mathrm{COOH}) .{ }^{13} \mathrm{C}-\mathrm{NMR}\left(\left(\mathrm{D}_{6}\right) \mathrm{DMSO}\right): 22.2\left(q, \mathrm{Me}_{2} \mathrm{C}\right) ; 40.6\left(s, \mathrm{Me}_{2} C\right) ; 72.3\left(t, \mathrm{CH}_{2} \mathrm{O}\right)$; $76.7\left(\mathrm{PhCH}_{2}\right) ; 127.2,127.3,128.1(3 d, 5$ arom. $\mathrm{CH}) ; 138.4(s, 1$ arom. $\mathrm{C}) ; 177.3(s, \mathrm{COOH})$. EI-MS: $208\left(7, M^{+^{+}}\right), 107(49), 91(100), 79(9), 65(9)$.

3-Benzyloxy-2,2-dimethyl-N-[1-methyl-1-(N-methyl-N-phenylcarbamoyl)ethyl]propanamide (15). To a soln. of $\mathbf{1 4}(800 \mathrm{mg}, 3.85 \mathrm{mmol})$ in THF (10 ml), a soln. of $\mathbf{5 b}(670 \mathrm{mg}, 3.85$ mmol) in THF ( $2 \mathrm{ml}$ ) was added dropwise. After $24 \mathrm{~h}$, the solvent was removed i.v. and the residue was purified by $\mathrm{CC}\left(\mathrm{CH}_{2} \mathrm{Cl}_{2} / \mathrm{MeOH} 40: 1\right)$. Yield: $1.230 \mathrm{~g}(84 \%)$ of 15 . White solid. M.p.105.6-106.8 ${ }^{\mathrm{o}}$ IR: 3339vs (NH), 2992m, 2956m, 2838m, 1644vs (C=O), 1593m, 1253s, 1103s (C-O), 976w, 753m, 713m, 618w. ${ }^{1} \mathrm{H}-\mathrm{NMR}: 0.98,1.31\left(2 s, 2 \mathrm{Me}_{2} \mathrm{C}\right) ; 3.08\left(s, \mathrm{CH}_{2} \mathrm{O}\right)$; $3.14(s, \mathrm{MeN}) ; 4.31\left(s, \mathrm{PhCH}_{2}\right) ; 6.96(s, \mathrm{NH}), 7.12-7.27$ (m, 10 arom. H). ${ }^{13} \mathrm{C}-\mathrm{NMR}: 22.8$, $26.4\left(2 q, 2 \mathrm{Me}_{2} \mathrm{C}\right) ; 41.2(q, \mathrm{MeN}) ; 42.5,57.4\left(2 s, 2 \mathrm{Me}_{2} C\right) ; 73.3\left(t, \mathrm{CH}_{2} \mathrm{O}\right) ; 76.4\left(t, \mathrm{PhCH}_{2}\right)$; 127.4, 127.5, 127.7, 127.9, 128.3, 129.1 ( $6 d, 10$ arom. $\mathrm{CH})$; 137.6, 145.1 (2s, 2 arom. C); 173.2, $175.2(2 s, 2 \mathrm{C}=\mathrm{O})$. ESI-MS: $405\left(100,[M+\mathrm{Na}]^{+}\right)$. 2-[(3-Benzyloxy-2,2-dimethylpropanoyl)amino]-2-methylpropanoic acid (16). To a soln. of $15(1.200 \mathrm{~g} 3.14 \mathrm{mmol})$ in THF $(5 \mathrm{ml}), 3 \mathrm{~N} \mathrm{HCl}(5 \mathrm{ml})$ was added dropwise at $0^{\circ}$. The mixture was left overnight at r.t., the org. solvent was evaporated i.v., and the residue was extracted with AcOEt. The combined org. fractions were washed with brine and dried $\left(\mathrm{MgSO}_{4}\right)$. After evaporation, the crystals were washed with $\mathrm{Et}_{2} \mathrm{O} /$ hexane $2: 1$. Yield: $818 \mathrm{mg}(89 \%)$. White crystals. M.p.109.4-110.2 ${ }^{\circ}$ IR: 3355vs (OH), 2989-2863s (br.), 1717vs (C=O), 1620vs $(\mathrm{C}=\mathrm{O}), 1533 \mathrm{v} s, 1468 s, 1397 s, 1257 s, 1162 s, 1162 s, 1092 \mathrm{v} s, 1012 m, 930 m, 8289 s, 753 s$, 704m, 693m. ${ }^{1} \mathrm{H}-\mathrm{NMR}: 1.17,1.46\left(2 s, 2 \mathrm{Me}_{2} \mathrm{C}\right) ; 3.44\left(s, \mathrm{CH}_{2} \mathrm{O}\right) ; 4.56\left(s, \mathrm{PhCH}_{2}\right) ; 7.31-7.39$ 
( $m, 5$ arom. H, NH). ${ }^{13} \mathrm{C}-\mathrm{NMR}: 22.8,24.8\left(2 q, 2 \mathrm{Me}_{2} \mathrm{C}\right) ; 42.5,56.6\left(2 s, 2 \mathrm{Me}_{2} C\right) ; 73.6(t$, $\left.\mathrm{CH}_{2} \mathrm{O}\right) ; 76.4\left(t, \mathrm{PhCH}_{2}\right) ; 127.6,127.9,128.4$ (3d, 5 arom. $\left.\mathrm{CH}\right) ; 137.2$ (s, 1 arom. C); 177.2, $178.0\left(2 s, 2\right.$ C=O). CI-MS: $294\left(100,[M+1]^{+}\right), 295(18)$.

2-Methyl-2-\{[1-methyl-1-(N-methyl-N-phenylcarbamoyl)ethyl]carbamoyl\}propyl 2-[(3Benzyloxy-2,2-dimethylpropanoyl)amino]-2-methylpropanoate (17). To a soln. of 16 (1.00 g, $3.41 \mathrm{mmol}$ ) in dry THF (15 ml), 1,1'-carbonyldiimidazol (CDI; $552 \mathrm{mg}, 3.41 \mathrm{mmol}$ ) was added. After $2 \mathrm{~h}$ stirring at r.t., $6 \mathbf{b}(934 \mathrm{mg}, 3.41 \mathrm{mmol})$ was added, followed by the dropwise addition of a Na-imidazolid suspension (73 mg imidazol, $45 \mathrm{mg}$ of a $60 \% \mathrm{NaH}$ suspension in mineral oil and $3 \mathrm{ml}$ of THF). After stirring overnight, the org. solvent was removed i.v. and the residue was purified by $\mathrm{CC}\left(\mathrm{CH}_{2} \mathrm{Cl}_{2}\right.$ /acetone 60:1). Yield: $1.276 \mathrm{~g}(66 \%)$ of 17. White solid. M.p. 114.2-115.8 ${ }^{\circ}$ IR: 3353s (NH), 2980m, 2934m, 2873m, 1739vs $(\mathrm{C}=\mathrm{O}), 1702 m, 1664 \mathrm{v} s$ (br., $\mathrm{C}=\mathrm{O}), 1594 s, 1520 s, 1494 m, 1454 m, 1385 m, 1382 m, 1150 v \mathrm{~s}(\mathrm{C}-$ O), $1091 m, 1023 m, 923 m, 904 m, 738 m, 705 m .{ }^{1} \mathrm{H}-\mathrm{NMR}: 1.13,1.14\left(2 s, 2 \mathrm{Me}_{2} \mathrm{C}\right) ; 1.44(s, 2$ $\left.M e_{2} \mathrm{C}\right) ; 3.27(s, \mathrm{MeN}) ; 3.42\left(s, \mathrm{CH}_{2} \mathrm{OH}\right) ; 4.03\left(s, \mathrm{CH}_{2} \mathrm{O}\right) ; 4.57\left(s, \mathrm{PhCH}_{2}\right) ; 7.04(s, \mathrm{NH}) ; 7.21-$ 7.41 (m, 10 arom. H, NH). ${ }^{13} \mathrm{C}-\mathrm{NMR}: 22.3,22.9,24.7,25.2\left(4 q, 4 \mathrm{Me}_{2} \mathrm{C}\right) ; 41.4(q, \mathrm{MeN})$; 42.5, 42.7, 55.8, $58.3\left(4 s, 4 \mathrm{Me}_{2} C\right) ; 70.9\left(t, \mathrm{CH}_{2} \mathrm{O}\right) ; 73.5\left(t, \mathrm{CH}_{2} \mathrm{O}\right) ; 76.6\left(\mathrm{PhCH}_{2}\right) ; 127.5$, 127.7, 128.0, 128.3, 128.3, 129.3 (6d, 10 arom. H); 137.6, 144.3 (2s, 2 arom. C); 173.6, 173.7, 174.0, $175.8(4 s, 4 \mathrm{C}=\mathrm{O})$. CI-MS: $590\left(100,[M+\mathrm{Na}]^{+}\right)$.

2-Methyl-2-\{[1-methyl-1-(N-methyl-N-phenylcarbamoyl)ethy]lcarbamoyl\}propyl 2-[(3Hydroxy-2,2-dimethylpropanoyl)amino]-2-methylpropanoate (11). To a soln. of 17 (1.200 g, $2.11 \mathrm{mmol})$ in dry $\mathrm{CH}_{2} \mathrm{Cl}_{2}(15 \mathrm{ml}), 150 \mathrm{mg}$ of $\mathrm{Pd} / \mathrm{C}$ were added and the mixture was stirred under an $\mathrm{H}_{2}$-atmosphere at r.t. overnight. The suspension was filtered over celite, and evaporated i.v. The product was used without further purification. Yield: 901mg (89\%) of 11. White crystals. M.p. 139.2-140.3․ IR: 3358vs (OH), 3281m, 2981m, 2886m, 1746vs (C=O), 1664vs, 1623vs, 1592s, 1533vs, 1382s, 1264s, 1224m, 1144vs, 1140m, 1062m, 1024w, 781m, 
708s. ${ }^{1} \mathrm{H}-\mathrm{NMR}\left(\left(\mathrm{D}_{6}\right) \mathrm{DMSO}\right): 0.99,1.04,1.31,1.38\left(4 s, 4 M e_{2} \mathrm{C}\right) ; 3.20(s, \mathrm{MeN}) ; 3.34\left(d,{ }^{3} J=\right.$ 6, $\left.\mathrm{CH}_{2} \mathrm{O}\right) ; 3.91\left(s, \mathrm{CH}_{2} \mathrm{O}\right) ; 4.97\left(t,{ }^{3} J=6, \mathrm{OH}\right) ; 7.16-7.28(m, 2$ arom. $\mathrm{H}, \mathrm{NH}) ; 7.30-7.40(m$, 3 arom. H); $7.58(s, \mathrm{NH}) .{ }^{13} \mathrm{C}-\mathrm{NMR}\left(\left(\mathrm{D}_{6}\right) \mathrm{DMSO}\right): 21.9,22.1,24.6,25.9\left(4 q, 4 \mathrm{Me}_{2} \mathrm{C}\right) ; 41.6$, 42.6, 54.8, $56.4\left(4 s, 4 \mathrm{Me}_{2} C\right) ; 67.5,69.9\left(2 t, 2 \mathrm{CH}_{2} \mathrm{O}\right) ; 126.3,127.0,128.7$ (3d, 5 arom. $\left.\mathrm{CH}\right)$; $137.8\left(s, 1\right.$ arom. C); 172.3, 173.6, 173.7, $175.61\left(4 s, 4\right.$ C=O). ESI-MS: $500\left(100,[M+\mathrm{Na}]^{+}\right)$.

\section{Formation of 2-(2-Hydroxy-1,1-dimethylethyl)-4,4-dimethyloxazol-5(4H)-one (19).}

Procedure F. A soln. of $\mathbf{1 8}$ (103 mg, $0.5 \mathrm{mmol})$ and $N, N^{\prime}$-dicyclohexylcarbodiimide (DCC; $104 \mathrm{mg}, 0.5 \mathrm{mmol})$ in AcOEt (10 ml) was stirred overnight at r.t., then filtered, washed with AcOEt, and the solvent was evaporated i.v. Recrystallisation of the residue from $\mathrm{MeCN}$ yielded 33mg (36\%) of 19 as white crystals. M.p. 128.1-128.8 ${ }^{\circ}$ IR: 3327vs (OH), 2928vs, 2850vs, 1836vs, 1626vs, 1574vs, 1536vs, 1436m, 1311s, 1271m, 1243s, 1088s, 1045m, 892m, 641s. ${ }^{1} \mathrm{H}-\mathrm{NMR}\left(\left(\mathrm{D}_{6}\right) \mathrm{DMSO}\right): 1.13,1.30\left(2 s, 2 \mathrm{Me}_{2} \mathrm{C}\right) ; 3.41\left(d,{ }^{3} \mathrm{~J}=6, \mathrm{CH}_{2} \mathrm{OH}\right) ; 4.91\left(t,{ }^{3} J=6\right.$, OH). ${ }^{13} \mathrm{C}-\mathrm{NMR}\left(\left(\mathrm{D}_{6}\right) \mathrm{DMSO}\right): 21.3,24.2\left(2 q, 2 \mathrm{Me}_{2} C\right) ; 64.9,67.4\left(2 s, 2 \mathrm{Me}_{2} C\right) ; 166.6(s$, $\mathrm{C}=\mathrm{N}) ; 181.8(s, \mathrm{C}=\mathrm{O})$. CI-MS: $204\left(100,\left[M+\mathrm{NH}_{4}\right]^{+}\right), 186\left(30,[M+1]^{+}\right), 174(10), 158(6)$. Procedure G. A soln. of $\mathbf{1 8}$ (103 mg, $0.5 \mathrm{mmol})$ and 1-[3-(dimethylamino)propyl]-3ethylcarbodiimide hydrochloride $(86 \mathrm{mg}, 0.5 \mathrm{mmol})$ in AcOEt $(10 \mathrm{ml})$ was stirred overnight at r.t., then washed with brine and extracted with AcOEt. The combined org. fractions were dried $\left(\mathrm{MgSO}_{4}\right)$, the solvent was evaporated i.v., and the residue purified by $\mathrm{CC}$ $\left(\mathrm{CH}_{2} \mathrm{Cl}_{2} /\right.$ acetone 150:1). Yield: $26 \mathrm{mg}(28 \%)$ of 19.

Procedure H. A soln. of $\mathbf{1 8}(103 \mathrm{mg}, 0.5 \mathrm{mmol})$ and 4-(dimethylamino)pyridine (DMAP; 66 $\mathrm{mg}, 0.5 \mathrm{mmol})$ in $\mathrm{CH}_{2} \mathrm{Cl}_{2}(10 \mathrm{ml})$ was stirred for $15 \mathrm{~min}$ at r.t. Then, DCC (103 $\mathrm{mg}, 0.5$ mmol) was added. The mixture was left overnight, then filtered, washed with AcOEt, and the solvent was evaporated i.v. Purification by $\mathrm{CC}\left(\mathrm{CH}_{2} \mathrm{Cl}_{2}\right.$ /acetone 150:1) yielded $42 \mathrm{mg}(45 \%)$ of 19. 
7. Synthesis and Cyclization of 1-Ethoxycarbonyl-1-methylethyl 3-Hydroxy-2,2-

dimetylpropanoate.

1-Ethoxycarbonyl-1-methylethyl 3-Benzyloxy-2,2-dimethylpropanoate (21). To a soln. of 14 (1.00 g, $3.41 \mathrm{mmol})$ in dry THF (15 ml), CDI (552 mg, $3.41 \mathrm{mmol})$ was added and the mixture was stirred at r.t. for $2 \mathrm{~h}$. Then, methyl 2-hydroxy-2,2-dimethylethanoate (450 mg, $3.41 \mathrm{mmol}$ ) was added followed by the dropwise addition of $3 \mathrm{ml}$ of a Na-imidazolid suspension (73 mg imidazole, $45 \mathrm{mg}$ of a $60 \% \mathrm{NaH}$ suspension in mineral oil and $3 \mathrm{ml} \mathrm{THF}$ ). After stirring overnight, the org. solvent was removed i.v. and the residue purified by CC $\left(\mathrm{CH}_{2} \mathrm{Cl}_{2}\right.$ /acetone 100:1). Yield: $780 \mathrm{mg}$ (48\%) of 21. Colorless oil. IR (film): 2983m, 1743vs $(\mathrm{C}=\mathrm{O}), 1471 w, 1383 w, 1293 m, 1179 s(\mathrm{C}-\mathrm{O}), 1130 s(\mathrm{C}-\mathrm{O}), 1028 m, 738 w, 698 w .{ }^{1} \mathrm{H}-\mathrm{NMR}:$ $1.21\left(s+t, \mathrm{Me}_{2} \mathrm{C}, \mathrm{MeCH}_{2} \mathrm{O}\right) ; 1.52\left(s, M e_{2} \mathrm{C}\right) ; 3.47\left(s, \mathrm{CH}_{2} \mathrm{O}\right) ; 3.76\left(q, \mathrm{MeCH}_{2} \mathrm{O}\right) ; 4.52(s$, $\left.\mathrm{PhCH}_{2}\right)$; 7.25-7.32 (m, 5 arom. H). ${ }^{13} \mathrm{C}-\mathrm{NMR}: 13.9$ (q, Me); 22.2, 24.3 (2q, $\left.2 \mathrm{Me}_{2} \mathrm{C}\right) ; 43.4(s$, $\left.\mathrm{Me}_{2} C\right) ; 60.9\left(t, \mathrm{Me} C \mathrm{H}_{2} \mathrm{O}\right) ; 73.2\left(t, \mathrm{CH}_{2} \mathrm{O}\right) ; 76.7\left(t, \mathrm{PhCH}_{2}\right) ; 77.9\left(s, \mathrm{Me}_{2} C\right) ; 127.2,127.3$, 128.1 (3d, 5 arom. CH); 138.5 ( $s, 1$ arom. CH); 172.5, 175.1 (2s, 2 C=O). ESI-MS: 345 (100, $\left.[M+\mathrm{Na}]^{+}\right)$

1-Ethoxycarbonyl-1-methylethyl 3-Hydroxy-2,2-dimethylpropanoate (22). To a soln. of 19 (900 mg, $2.61 \mathrm{mmol}$ ) in dry $\mathrm{CH}_{2} \mathrm{Cl}_{2}(15 \mathrm{ml}), 120 \mathrm{mg}$ of $\mathrm{Pd} / \mathrm{C}$ were added and the mixture was stirred under $\mathrm{H}_{2}$-atmosphere at r.t. overnight. The suspension was filtered over celite, and evaporated i.v. The product was used without further purification. Yield: $777 \mathrm{mg}$ (91\%) of 22. Colorless oil. IR (film): 3528w (br.), 2885m, 2939m, 1743vs (C=O), 1474m, 1296s, $1180 m(\mathrm{C}-\mathrm{O}), 1128 s(\mathrm{C}-\mathrm{O}), 1053 m, 882 w, 758 w, 670 w .{ }^{1} \mathrm{H}-\mathrm{NMR}: 1.11\left(s, \mathrm{Me}_{2} \mathrm{C}\right) ; 1.22(t$, $\left.M e \mathrm{CH}_{2} \mathrm{O}\right) ; 1.53\left(2 s, 2 \mathrm{Me}_{2} \mathrm{C}\right) ; 3.53\left(d, \mathrm{CH}_{2} \mathrm{OH}\right) ; 4.13\left(q, \mathrm{MeCH}_{2} \mathrm{O}\right) .{ }^{13} \mathrm{C}-\mathrm{NMR}: 13.8(q, \mathrm{Me})$; 21.5, $24.4\left(2 q, 2 \mathrm{Me}_{2} \mathrm{C}\right) ; 44.3\left(s, \mathrm{Me}_{2} C\right) ; 61.3\left(t, \mathrm{MeCH}_{2} \mathrm{O}\right) ; 70.0\left(t, \mathrm{CH}_{2} \mathrm{O}\right) ; 78.5\left(s, \mathrm{Me}_{2} C\right)$; 172.6, $176.1(2 s, 2 \mathrm{C}=\mathrm{O})$. ESI-MS: $255\left(100,[\mathrm{M}+\mathrm{Na}]^{+}\right)$. 
3,3,7,7,11,11-Hexamethyl-1,5,9-trioxacyclododecane-2,6,10-trione (23) and

3,3,7,7,11,11,15,15-Octamethyl-1,5,9,13-tetraoxacyclohexadecane-2,6,10,14-tetraone (24).

To a soln. of $22(232 \mathrm{mg}, 1 \mathrm{mmol})$ in dry toluene $(5 \mathrm{ml})$, NaH (40 $\mathrm{mg}$ of a $60 \%$ suspension in mineral oil, $1 \mathrm{mmol})$ was added slowly at $0^{\circ}$ and under constant stirring $\left(\mathrm{N}_{2}\right.$-atmosphere $)$. After $5 \mathrm{~h}$ at $80^{\circ}$, the mixture was acidified with $0.1 \mathrm{~N} \mathrm{HCl}(\sim 6 \mathrm{ml})$ to $\mathrm{pH} 5$ and extracted with $\mathrm{CH}_{2} \mathrm{Cl}_{2}$. The combined org. fractions were dried $\left(\mathrm{MgSO}_{4}\right)$ and evaporated i.v. The crystalline residue was purified by $\mathrm{CC}\left(\mathrm{CH}_{2} \mathrm{Cl}_{2} /\right.$ acetone 200:1) to yield $24 \mathrm{mg}$ (8\%) of 23. M.p. [57] and $38 \mathrm{mg}(9.5 \%)$ of $24[57]$.

8. X-ray Crystal-Structure Determination of 6a, 6b, 10, 11, 18, 19, and 23 (Table and Figs. $1-5)^{3)}$. All measurements were made on a Nonius KappaCCD diffractometer [58] using graphite-monochromated $\mathrm{Mo} K_{\alpha}$ radiation $(\lambda 0.71073 \AA$ ) and an Oxford Cryosystems Cryostream 700 cooler. The data collection and refinement parameters are given in the Table and views of the molecules are shown in Figs. 1-5. Data reductions were performed with $H K L$ Denzo and Scalepack [59]. The intensities were corrected for Lorenz and polarization effects, but not for absorption. The structures were solved by direct methods using SIR92 [60], which revealed the positions of all non-H atoms. There were two symmetry-independent molecules in the asymmetric unit of $\mathbf{6 b}, \mathbf{1 9}$ and $\mathbf{2 3}$. In each case the atomic coordinates of the two molecules were tested carefully for a relationship from a higher symmetry space group using the program PLATON [61], but none could be found. The non-hydrogen atoms were refined anisotropically. Except for 10, the amide and hydroxy H-atoms in the structures were placed

\footnotetext{
${ }^{3}$ ) CCDC- 210670-210676 contain supplementary crystallographic data for this paper. These data can be obtained free of charge via www.ccdc.cam.ac.uk/conts/retrieving.html (or form the Cambridge Crystallographic Data Centre, 12 Union Road, Cambridge CB12 1EZ, U.K. (fax : +44-(0)1223-336033; e-mail: deposit@ccdc.cam.ac.uk))
} 
in the positions indicated by difference electron density maps and their positions were allowed to refine together with individual isotropic displacement parameters. All remaining $\mathrm{H}$-atoms in all structures were placed in geometrically calculated positions and each was assigned a fixed isotropic displacement parameter with a value equal to $1.2 U_{\text {eq }}$ of its parent atom $\left(1.5 U_{\text {eq }}\right.$ for the Me groups of $\mathbf{6 a}, \mathbf{1 1}, \mathbf{1 9}$ and $\left.\mathbf{2 3}\right)$. For $\mathbf{6 b}, \mathbf{1 0}$ and $\mathbf{1 8}$, each structure was refined on $F$ using full-matrix least-squares procedures, which minimized the function $\Sigma w\left(\left|F_{\mathrm{o}}\right|\right.$ $\left.-\left|F_{\mathrm{c}}\right|\right)^{2}$. Refinement of the remaining structures was carried out on $F^{2}$ by minimizing the corresponding function based on $F^{2}$. Corrections for secondary extinction were applied with the exception of $\mathbf{1 8}$. In $\mathbf{6 b}, \mathbf{1 0}, \mathbf{1 1}, 18$ and $\mathbf{2 3}$, six, two, one, three and three reflections, respectively, were omitted from the final refinement of each structure because their observed intensities were much lower than the calculated values as a result of being partially obscured by the beam stop. Neutral atom scattering factors for non-H atoms were taken form [62a] and the scattering factors for $\mathrm{H}$-atoms were taken from [63]. Anomalous dispersion effects were included in $\mathrm{F}_{\mathrm{c}}$ [64]; the values for $f^{\prime}$ and $f^{\prime \prime}$ were those of [62b]. The values of the mass attenuation coefficients are those of [62c]. All calculations were performed using the teXsan crystallographic software package [65] for $\mathbf{6 b}, \mathbf{1 0}$, and $\mathbf{1 8}$ and the SHELXL97 program [66] for $\mathbf{6 a}, \mathbf{1 1}, \mathbf{1 9}$, and $\mathbf{2 3}$, respectively.

\section{REFERENCES}

[1] H. Vervoort, W. Fenical, R. de Epifanio, J. Org. Chem. 2000, 65, 782.

[2] N. Sitachitta, R. T. Williamson, W. H. Gerwick, J. Nat. Prod. 2000, 63, 197.

[3] F. D. Horgan, D. B. de los Santos, G. Goetz, B. Sakamoto, Y. Kan, H. Nagai, P. J. Scheuer, J. Nat. Prod. 2000, 63, 152.

[4] K. Fujii, K. Sivinen, E. Naganawa, K. Harada, Tetrahedron 2000, 56, 725.

[5] B. N. Belofski, P. R. Jensen, W. Fenical, Tetrahedron Lett. 1999, 40, 2913. 
[6] A. K. Gosh, A. Bischoff, Org. Lett. 2000, 2, 1573.

[7] F. Sarabia, S. Chammaa, F. J. Lopez-Herrera, Tetrahedron Lett. 2002, 43, 2961.

[8] J. Hong, L. Zhang, Frontiers of Biotechnology \& Pharmaceuticals 2002, 3, 193.

[9] K. Brockmann, G. Schmidt-Kastner, Chem. Ber. 1955, 88, 57.

[10] M. M. Shemyakin, N. A. Aldanova, R. I. Vinogradova, V. Y. Feigina, Tetrahedron Lett. 1963, 28, 1921.

[11] B. C. Pressman, E. J. Harris, W. S. Jagger, J. N. Johnson, Procl. Nat. Acad. Sci. U.S.A. 1967, 58, 1949.

[12] Y. A. Ovchinnikov, V. T. Ivanov, A. V. Evstratov, I. I. Mikhaleva, V. F. Bystrov, S. L. Portnova, T. A. Balashova, E. N. Meshcheryakova, V. M. Tul'chinskii, Int. J. Pept. Protein Res. 1974, 6, 465.

[13] B. C. Pressman, Ann. Rev. Biochem. 1976, 45, 501.

[14] A. M. Sefler, M. C. Kozlowski, T. Guo, P. A. Bartlett, J. Org. Chem. 1977, 62, 93.

[15] Y. L. Dory, J. M. Mellor, J. F. McAleer, Tetrahedron Lett. 1996, 52, 1343.

[16] T. Imaeda, Y. Hamada, T. Shioiri, Tetrahedron Lett. 1994, 35, 591.

[17] K. W. Li, J. Wu, W. Xing, J. A. Simpson, J. Am. Chem. Soc. 1996, 118, 7237.

[18] Y. Hirai, K. Yokota, T. Momose, Heterocycles 1994, 39, 603.

[19] S. Cerini, E. Gavuzzo, G. Luisi, F. Pinnen, Int. J. Pept. Protein Res. 1993, 41, 282.

[20] T. K. Chakraboity, S. Ghosh, S. Dutta, Tetrahedron Lett. 2001, 45, 5085.

[21] M. Eggen, S. K. Nair, G. I. Georg, Org. Lett. 2001, 3, 1813.

[22] D. Obrecht, H. Heimgartner, Helv. Chim. Acta 1984, 67, 526.

[23] D. Obrecht, H. Heimgartner, Helv. Chim. Acta 1987, 70, 329.

[24] D. Obrecht, H. Heimgartner, Helv. Chim. Acta 1990, 73, 221.

[25] J. M. Villagordo, H. Heimgartner, Helv. Chim. Acta 1997, 80, 748.

[26] K. N. Koch, A. Linden, H. Heimgartner, Helv. Chim. Acta 2000, 83, 233. 
[27] K. N. Koch, A. Linden, H. Heimgartner, Tetrahedron 2001, 57, 2311.

[28] H. Heimgartner, F. S. Arnhold, S. Fritschi, K. N. Koch, A. Linden; J. E. F. Magirius, J. Heterocycl. Chem. 1999, 36, 1539.

[29] A. Linden, F. Ghorbani-Salman Pour, R. A. Breitenmoser, H. Heimgartner, Acta Cryst., Sect. C 2001, 57, 634.

[30] K. N. Koch, H. Heimgartner, Helv. Chim. Acta 2000, 83, 1881.

[31] H. Heimgartner, Angew. Chem., Int. Ed. Engl. 1991, 30, 238.

[32] C. B. Bucher, A. Linden, H. Heimgartner, Helv. Chim. Acta 1995, 78, 935; C. B. Bucher, H. Heimgartner, Helv. Chim. Acta 1996, 79, 1903.

[33] R. Luykx, C. B. Bucher, A. Linden, H. Heimgartner, Helv. Chim. Acta 1996, 79, 527.

[34] G. Suter, S. Stoykova, A. Linden, H. Heimgartner, Helv. Chim. Acta 2000, 83, 2961.

[35] K. Brun, A. Linden, H. Heimgartner, Helv. Chim. Acta 2002, 85, 3422; K. Brun, A.

Linden, H. Heimgartner, Helv. Chim. Acta 2001, 84, 1756-1777.

[36] R. A. Breitenmoser, T. Hirt, R. T. N. Luykx, H. Heimgartner, Helv. Chim. Acta 2001, $84,972$.

[37] P. Wipf, H. Heimgartner Helv. Chim. Acta 1990, 73, 13.

[38] N. Pradeille, H. Heimgartner J. Pept. Sci. 2003, in press.

[39] W. Altherr, Ph.D. Thesis, Universität Zürich, 1994.

[40] R. T. N. Luykx, Ph.D. Thesis, Universität Zürich, 2000.

[41] C. K. Johnson, 'ORTEP II', Report ORNL-5138, Oak Ridge National Laboratory, Oak Ridge, Tennessee, 1976.

[42] J. Bernstein, R. E. Davis, L. Shimoni, N.-L. Chang, Angew. Chem. Int. Ed. 1995, 34, 1555.

[43] N. M. Mawad, F. Ghorbani-Salman Pour, A. Linden, H. Heimgartner, in preparation. [44] K. C. Nicolaou, Tetrahedron 1977, 33, 683 
[45] J. Inanaga, K. Hirata, H. Saeki, T. Katsuki, M. Yamaguchi, Bull. Chem. Soc. Jpn. 1976, $52,1989$.

[46] E. J. Corey, K. C. Nicolaou, J. Am. Chem. Soc. 1974, 96, 5614.

[47] T. Mukaiyama, M. Usui, K. Saigo, Chem. Lett. 1976, 49.

[48] M. Hikota, H. Tone, K. Horita, O. Yonemitsu, J. Org. Chem. 1990, 55, 7.

[49] G. E. Keck, E. P. Boden, M. R. Wiley, J. Org. Chem. 1989, 54, 896.

[50] Y. Kuroki, K. Ishihara, N. Hanaki, S. Ohara, H. Yamamoto. Bull. Chem. Soc. Jpn. 1998, $71,1221$.

[51] K. Steliou, A.Szczygielska-Nowosielska, A. Farve, M. A. Poupart, S. Hanessian, J. Am. Chem. Soc. 1980, 102, 7578.

[52] K. R. Buszek, Y. Jeong, N. Sato, P. C. Still, P. L. Muino, I. Ghosh, Synth. Commun. 2001, 31, 1781 .

[53] K. Ishihara, M. Kubota, H. Kurihara, H. Yamamoto, J. Am. Chem. Soc. 1995, 117, 4413.

[54] B. M. Trost, J. D. Chisholm, Org. Lett. 2002, 4, 3743.

[55] T. Fujita, N. Hanyu, T. Mino, M. Sakamoto, Synthesis 2001, 12, 1846.

[56] S. Richard, G. Prie, A. Guignard, J. Thibonet, J. Luc Parrain, A. Duchene, M. Abarbri, Helv. Chim. Acta 2003, 86, 726.

[57] A. Matuszowicz, Z. Jedlinski, M. Gawron, Z. Kosturkiewicz, J. Org. Chem. 1995, 60, 6826.

[58] R. Hooft, KappaCCD Collect Software, Nonius BV, Delft, The Netherlands, 1999. [59] Z. Otwinowski, W. Minor, in 'Methods in Enzymology', Vol. 276, 'Macromolecular Crystallography', part A, Eds. C. W. Carter Jr., R. M. Sweet, Academic Press, New York, 1997, p. 307.

[60] A. Altomare, G. Cascarano, C. Giacovazzo, A. Guagliardi, M. C. Burla, G. Polidori, M. Camalli, SIR92, J. Appl. Crystallogr. 1994, 27, 435. 
[61] A. L. Spek, PLATON, J. Appl. Crystallogr. 2003, 36, 7.

[62] a) E. N. Maslen, A. G. Fox, M. A. O'Keefe, in 'International Tables for

Crystallography', Ed. A. J. C. Wilson, Kluwer Academic Publishers, Dordrecht, 1992 Vol. C,

Table 6.1.1.1, p. 477; b) D. C. Creagh, W. J. McAuley, ibid. Table 4.2.6.8, p. 219; c) D. C.

Creagh, J. H. Hubbell, ibid. Table 4.2.4.3, p. 200.

[63] R. F. Steward, E. R. Davidson, W. T. Simpson, J. Chem. Phys. 1965, 42, 3175.

[64] J. A. Ibers, W. C. Hamilton, Acta Crystallogr. 1964, 17, 781.

[65] teXsan: Single Crystal Structure Analysis Software, Version 1.10, Molecular Structure

Corporation, The Woodlands, Texas, 1999.

[66] G. M. Sheldrick, SHELXL97, Program for the Refinement of Crystal Structures, University of Göttingen, Germany, 1997. 